\title{
Disease: A Hitherto Unexplored Constraint on the Spread of Dogs (Canis lupus familiaris) in Pre-Columbian South America
}

\author{
Peter Mitchell ${ }^{1}$
}

Published online: 18 November 2017

(C) The Author(s) 2017. This article is an open access publication

\begin{abstract}
Although debate continues, there is agreement that dogs (Canis lupus familiaris) were first domesticated in Eurasia, spreading from there to other parts of the world. However, while that expansion already extended as far as Europe, China, and North America by the early Holocene, dogs spread into (and south of) the tropics only much later. In South America, for example, the earliest well-attested instances of their presence do not reach back much beyond $3000 \mathrm{cal}$. BC, and dogs were still absent from large parts of the continent-Amazonia, the Gran Chaco, and much of the Southern Cone-at European contact. Previous explanations for these patterns have focused on cultural choice, the unsuitability of dogs for hunting certain kinds of tropical forest prey, and otherwise unspecified environmental hazards, while acknowledging that Neotropical lowland forests witness high rates of canine mortality. Building on previous work in sub-Saharan Africa (Mitchell in Archaeol Res Afr 50:92-135, 2015), and noting that the dog's closest relatives, the grey wolf (C. lupus) and the coyote $(C$. latrans), were likewise absent from South and most of Central America in pre-Columbian times, this paper explores instead the possibility that infectious disease constrained the spread of dogs into Neotropical environments. Four diseases are considered, all likely to be native and/ or endemic to South America: canine distemper, canine trypanosomiasis, canine rangeliosis, and canine visceral leishmaniasis caused by infection with Leishmania amazonensis and L. colombiensis. The paper concludes by suggesting ways in which the hypothesis that disease constrained the expansion of dogs into South America can be developed further.
\end{abstract}

Peter Mitchell

peter.mitchell@st-hughs.ox.ac.uk

1 School of Archaeology, University of Oxford and GAES, University of the Witwatersrand St Hugh's College, Oxford OX2 6LE, UK 
Keywords Dog · Expansion · Tropics · South America · Pre-Columbian · Infectious diseases

\section{Introduction}

The precise origins of the domestic dog (Canis lupus familiaris) remain contentious, though zoologists agree that its ancestor was the grey wolf (C. lupus). Both the timing of the canine domestication process and its location continue to be debated, along with whether domestication took place just once or on multiple occasions, perhaps in different places (Freedman and Wayne 2017). The likelihood of ongoing admixture between dog and wolf populations over several millennia complicates the picture still further, as do different estimates of the mutation rates involved and conflicting interpretations of potentially relevant faunal remains (Larson and Bradley 2014; Larson et al. 2012). Whatever the outcome of these debates-which I review briefly below-it is clear that the dog had reached further than any other domesticated plant or animal by the time Columbus crossed the Atlantic in 1492 and thereby paved the way for that large-scale exchange of plants, animals, microbes, and people that Alfred Crosby (1986) has dubbed the Columbian Exchange. Though they were not completely universal (e.g. Boyce 2006), dogs were nevertheless already global in their overall distribution long before that exchange got underway.

Perhaps because of its presumed antiquity or perhaps because the advantages of keeping dogs have been thought to be self-evident, how that situation was reached has received less attention than the question of where wolves became dogs in the first place. Though showing considerable interest in how people related to dogs (e.g. Morey 2006; Morey and Jeger 2017), archaeologists have, until recently, devoted less effort to exploring the circumstances in which they spread. And yet, as Larson et al. (2012) pointed out some years ago, a striking contrast is apparent in the archaeologically documented presence of dogs between much of Eurasia and North America on the one hand and the tropics on the other. Whatever view one takes regarding the date of their initial domestication, hunter-gatherers unquestionably kept dogs in northern China, Russia's Far East, Europe, and at least some parts of the Middle East prior to 10,000 years ago. They are documented in the Western and Midwestern United States only shortly thereafter, and in early pastoralist contexts in Egypt's Western Desert by around 6000 BC. This widespread late Pleistocene/early Holocene distribution is not, however, matched south of $20^{\circ} \mathrm{N}$. Instead, from Central and South America to sub-Saharan Africa to Southeast Asia (including southern China and Indochina) and Australasia, the archaeological records of four continents struggle to identify the dog beyond 5000 years ago (Larson et al. 2012; Mitchell 2015; Piper 2017; Stahl 2012). Indeed, in some regions, notably Africa south of the Equator or-as we shall see-much of South America, dogs first appeared much more recently than that.

Latitudinal gradients of this kind have long been noted with respect to other domesticates. Jared Diamond (1997), for example, has emphasised the importance of geographical axis with respect to the spread of staple crops such as maize (Zea mays) in the New World. Originating in west-central Mexico from the tropical grass 
teosinte (Piperno et al. 2009), maize had to cope with shorter, cooler growing seasons as it expanded north into the more temperate climes of the United States and Canada. One of the preconditions for its widespread adoption there was thus the evolution of races able to do precisely this (Hart and Lovis 2013), though its largescale cultivation may also have depended on combining it with beans (Phaseolus vulgaris), which faced similar challenges (Monaghan et al. 2014), in order to obtain the full range of essential amino-acids and a means of replenishing soil fertility. The history of plant cultivation in Africa shows a similar picture: introduced from the Near East, winter-rainfall-dependent wheat (Triticum dicoccum, T. monococcum) and barley (Hordeum vulgare) readily found new homes in North Africa, highland Ethiopia, and —using irrigation-Egypt, Nubia, and many Saharan oases. However, the shift to a summer-rainfall regime prohibited their cultivation south of the desert, with the result that sub-Saharan Africa's staple cereals instead took the form of indigenously domesticated sorghum (Sorghum bicolor), pearl millet (Pennisetum americanum), and finger millet (Eleusine coracana), plus others of much more restricted distribution (Fuller and Hildebrand 2013). But though fundamental to the subsistence strategies of savannah agriculturalists from Mali to Mozambique, in southern Africa these grasses too reached an ecological frontier as summer rains fell below the amounts they required in the semi-arid Kalahari and Karoo or, in South Africa's Eastern Cape Province, gave way to a year-round rainfall regime. Bantuspeaking agropastoralists therefore remained confined to areas north and east of the $500 \mathrm{~mm}$ isohyet (Huffman 1996), and farming was only introduced to the Mediterranean-like regions of the Cape by the Dutch in 1652 (Mitchell 2002).

In contrast to wheat and barley, domestic animals of Near Eastern origin-cattle (Bos taurus), sheep (Ovis aries), and goats (Capra hircus) - did reach the Cape in pre-colonial times. However, their expansion through Africa was far from smooth or unchequered. With respect to cattle, in particular, Diane Gifford-Gonzalez $(2000,2017)$ has explored the likelihood that diseases endemic to Africa south of the Sahara constrained the speed with which livestock-keeping could expand and the directions which that expansion could follow, in some regions precluding it altogether (e.g. Phillipson 1979, pp. 14, 17; Plug 1989, 1997) and frequently favouring the keeping of sheep and/or goats over cattle. Hosted by ungulates native to sub-Saharan Africa and easily spread via ticks or biting flies, pathogens such as those responsible for East Coast fever, Corridor disease, wildebeest-derived malignant catarrhal fever, and trypanosomiasis (nagana) posed a serious threat to the survival of incoming livestock that had evolved in Eurasian (and, for cattle, North African) environments where these diseases, their reservoirs, and their vectors were not found (Gifford-Gonzalez 2000, 2017; see also Wright 2011).

Encouraged by the strength of Gifford-Gonzalez's arguments with respect to the relatively slow, late, and partial expansion of livestock into eastern and southern Africa, I have suggested that disease may also have constrained the spread of the domestic dog into the tropics (Mitchell 2015). The basis of this argument lies in the recognition that the dog's wild ancestor, the grey wolf, is not a tropical animal and that when they entered the tropics dogs probably therefore encountered a range of parasites with which they had no prior familiarity. This may have been all the more likely where other wild canid species were present, since pathogens and vectors 
already adapted to those taxa may have found it relatively easy to 'jump ship' and include dogs among their targets. Lacking any previous history of exposure, dogs, on the other hand, can be expected to have found such pathogens significantly more dangerous than did native canids that had co-evolved with them over hundreds of thousands, if not millions, of years.

At least five infections seem relevant as potential constraints on the expansion of the dog south of the Sahara: canine trypanosomiasis, canine babesiosis, canine monocytic ehrlichiosis, visceral leishmaniasis and, possibly, African horse sickness (Mitchell 2015, 2017). All save leishmaniasis present severe disease challenges to dogs in Africa today. In some cases-for example, trypanosomiasis caused by infection with Trypanosoma brucei brucei (Matete 2003; Morrison et al. 1980) fatality rates as high as $100 \%$ continue to be recorded. Significantly, however, some dogs of African (rather than European) origin show partial tolerance to several of these conditions, while endemic wild canid species-black-backed jackals $(C$. mesomelas), side-striped jackals (C. adustus), and African hunting dogs (Lycaon pictus) - generally show no overt clinical signs of infection (e.g. Alexander et al. 1995; Penzhorn 2011; van Heerden 1979). Collectively, these observations, which are supported by experimental studies of infection under clinical conditions, suggest that disease did indeed restrict and constrain the ability of dogs to colonise much of the African continent. As a result, while dogs spread relatively quickly into North Africa, the Sahara, and Nubia-probably in association with early pastoraliststheir expansion beyond these regions was a very much later phenomenon: currently, for example, there is no archaeozoological evidence for their presence in southern Africa earlier than the sixth to eighth centuries cal. AD, nor in East Africa before the very end of the first millennium AD (Larson et al. 2012, Table S3; Mitchell 2015).

In this paper I explore the possibility that infectious disease also constrained the spread of dogs into a second continent, South America. As we shall see, there is no convincing evidence that they had spread south of the Isthmus of Panama before 3000 cal. BC, and dogs were still absent from large areas of South America (Amazonia, the Gran Chaco, and most of Argentina) even as recently as the onset of European exploration and colonisation in the sixteenth century. This general pattern has been noted previously and several explanations have been offered for it. Stahl (2012), for example, argues that cultural attitudes regarding the appropriate relations between humans and animals led people to reject domestication (dogs included). He also raises the possibility that prior possession of tamed but originally wild, endemic South American canids, which were in any case better suited to local conditions, could have discouraged adoption of the dog in some areas, especially Amazonia (Stahl 2013). Koster (2009) likewise stresses cultural choice, perhaps linked to the particular hunting strategies people employed. He also notes otherwise unspecified environmental hazards and high rates of canine mortality in Neotropical lowland forest environments. At the same time, an extensive literature has developed regarding the possibility that domestic dogs in South America today pose a health threat to wild animals, especially wild canids, by acting as reservoirs for a number of infectious and parasitic diseases (Woodroffe et al. 2004). However, archaeologists do not seem to have previously considered the possibility that diseases 
already endemic to South America might help explain the dog's staggered and partial expansion into that continent.

To address this I first briefly situate the history of the dog in South America within what we currently know of canine domestication at the global scale. I then review the archaeological evidence for the dog's antiquity, cultural associations, and overall distribution in South America as recorded by archaeological evidence, early European observers, and professional anthropologists. Next, I note that several important canine diseases present in South America today are known to have been introduced since 1492, raising the question of whether others were present beforehand. I then explore four such possibilities: canine distemper, canine Chagas disease, canine rangeliosis, and visceral leishmaniasis. I review the epidemiology, pathology, and current distribution of each disease, as well as what, if anything, is known about its history. I conclude by discussing some of the ways in which the hypothesis that disease constrained the expansion of dogs into and through South America could be evaluated further.

\section{The Global Background to Dogs in South America}

Genetic and archaeozoological research has produced contradictory results regarding the location and timing of the evolution of grey wolves into dogs. One quite comprehensive genetic study suggests a single origin some 15,000 years ago, followed by further admixture with wolves during the ensuing domestication process (Freedman et al. 2014), but rejects the specifically East Asian centre of domestication proposed previously on the basis of mitochondrial DNA (mtDNA) and Y chromosome data (Ding et al. 2012; Pang et al. 2009; Savolainen et al. 2002). A broadly Asian source is, however, indicated by another study that compared variability in selected components of the nuclear DNA of European and Asian dogs (Niskanen et al. 2013), while a third investigation, which focused on autosomal as well as mtDNA and Y chromosome diversity, points to Central Asia (Shannon et al. 2015). Ancient mtDNA recovered from a 33,000-year-old canid from southern Siberia's Altai Mountains that aligns it with dogs, rather than wolves, also highlights this general area, but at a much earlier period (Druzhkova et al. 2013). The possibility that dogs were domesticated earlier in the late Pleistocene than generally believed is also raised by Thalmann et al. (2013), who locate their origins in Europe some 19,000-32,000 years ago, a possibility canvassed on osteological grounds by Germonpré et al. (2009, 2012, 2015) and recently popularised by Shipman (2015). However, the biometric basis for identifying any large canids in Early Upper Palaeolithic Europe as dogs remains controversial (Boudadi-Maligne and Escarguel 2014; Morey 2014). So, too, do the taphonomic, ethnographic, and theoretical arguments adduced in its support (Perri et al. 2015).

A potential solution to at least some of these conflicting scenarios comes from the analysis by Frantz et al. (2016) of the nuclear genome of a Neolithic dog from Newgrange, Ireland, and of the ancient mtDNA of a further 59 European dogs. Both datasets were then compared with a large sample of modern animals. The results identify a marked divergence between modern East Asian and western Eurasian 
dogs that long pre-dates the 4800-year-old individual from Newgrange and likely 'occurred commensurate with, or several millennia after, the earliest known appearance of domestic dogs' in Europe and East Asia (Frantz et al. 2016, p. 1230). Putting to one side the claims for a much older Early Upper Palaeolithic domestication discussed above and comparing their genetic data with the archaeological evidence for domestic dogs, Frantz and colleagues find that the oldest securely identified dogs date to around 15,000 years ago in western Eurasia and to about 12,500 years ago in eastern Siberia. Pending the results of much broader, ongoing investigations, this evidence, plus the absence of domestic dogs from central Eurasia until around $8000 \mathrm{cal}$. BP, leads them to propose two separate late Palaeolithic domestication events at broadly opposite ends of the Eurasian continent, followed by an early Holocene partial replacement of western Eurasian dogs by others of East Asian ancestry (see also Morey and Jeger 2017, p. 898).

To situate South American dogs within this evolving picture, both archaeozoological and genetic evidence are required. Genetic studies of living and ancient dogs in the New World show that all descend from Eurasian grey wolves, with relatively little admixture from the latter's North American relatives (van Asch et al. 2013; Witt et al. 2015). The oldest archaeological remains of relevance to the dog's introduction to the Americas consist of two finds. A complete and deliberately buried skeleton from Ushki 1 near the east coast of Russia's Kamchatka Peninsula, immediately to the west of the Bering Sea, is dated to between 12,900 and 12,600 cal. BP (Dikov 1996), while a juvenile animal, identified as a 'probable dog', from Ust'-Khaita to the west of Lake Baikal in south-central Siberia is directly dated to between 12,380 and 12,135 cal. BP (Losey et al. 2013). Neither of these individuals is older than human presence in the Americas itself, which finds from sites like Monte Verde, Chile (Dillehay 2000), and Paisley Cave, Oregon (Jenkins et al. 2012), now place beyond 14,000 years ago, and perhaps as early as 18,000 years ago (Dillehay et al. 2015). However, they are sufficiently old not to exclude the possibility, discussed by Fiedel (2005), that dogs accompanied some of the first human settlers to expand through Beringia and on into the New World.

The archaeological record for the dog in the New World does not currently extend back into the late Pleistocene, but it does register its presence in at least two quite different regions of the continental United States by 9000-10,000 cal. BP, at Danger Cave in Utah (Lupo and Janetski 1994) and Koster, Illinois (Morey and Wiant 1992); Hinds Cave in Texas (Tito et al. 2011) may represent a third example (though see Larson et al. 2012, Table S2). Thereafter, several finds of mid-Holocene age are known, with many more documented from more recent times (Larson et al. 2012, Table S3; Morey 2006). As I now go on to show, however, a comparably early presence for the dog in Central and South America cannot be established, and even in the well-studied Andean region is difficult to demonstrate before $3000 \mathrm{cal}$. BC. 


\section{Archaeological Evidence for the Spread and Cultural Associations of the Dog in South America}

One of the factors complicating the picture is the fact that dogs were not the only canids in pre-Columbian South America. Thirteen other taxa survived the Pleistocene, eleven of which still exist today (Table 1). Having evolved in North America, their ancestors reached the continent as part of the Great American Biotic Interchange around three million years ago, when the formation of the Isthmus of Panama created a land bridge between Central and South America. In addition to the grey fox (Urocyon cinereoargenteus), which also occurs in North and Central America, South America's canids fall into two distinct lineages, both now endemic to the continent (Perini et al. 2010). The first of these comprises three further fox genera [Atelocynus microtis, Cerdocyon thous, and Pseudalopex (previously sometimes described as Lycalopex or Dusicyon) spp.], while the second consists of two somewhat more wolf-like species, the maned wolf (Chrysocyon brachyurus) and the bush dog (Speothos venaticus). Fossil evidence from North America

Table 1 Wild canid species native to South America

\begin{tabular}{|c|c|c|}
\hline Scientific name & $\begin{array}{l}\text { Common } \\
\text { English name }\end{array}$ & Historical distribution \\
\hline Atelocynus microtis & Short-eared dog & Lowland forests of western Amazonia \\
\hline Cerdocyon thous & Crab-eating fox & Colombia/Venezuela to Paraguay/northern Argentina \\
\hline $\begin{array}{l}\text { Chrysocyon } \\
\text { brachyurus }\end{array}$ & Maned wolf & $\begin{array}{l}\text { Central and southern Brazil, eastern Bolivia, Paraguay, } \\
\text { northern Argentina, Uruguay }\end{array}$ \\
\hline Dusicyon avus & $\begin{array}{l}\text { South American } \\
\text { fox }\end{array}$ & $\begin{array}{l}\text { Argentine Pampas, Patagonia, Tierra del Fuego, Uruguay } \\
\text { (extinct) }\end{array}$ \\
\hline Dusicyon australis & $\begin{array}{l}\text { Falkland Islands } \\
\text { wolf }\end{array}$ & Falkland Islands (extinct) \\
\hline $\begin{array}{l}\text { Pseudalopex } \\
\text { culpaeus }^{\mathrm{a}}\end{array}$ & Culpeo & $\begin{array}{l}\text { Southern Colombia to Tierra del Fuego in Andes and adjacent } \\
\text { hilly regions }\end{array}$ \\
\hline $\begin{array}{l}\text { Pseudalopex } \\
\text { fulvipes }^{\mathrm{a}}\end{array}$ & Darwin's fox & Chiloe Island, Chile \\
\hline $\begin{array}{l}\text { Pseudalopex } \\
\text { griseus }^{\mathrm{a}}\end{array}$ & Chilla & Northern Chile to Tierra del Fuego on both sides of the Andes \\
\hline $\begin{array}{l}\text { Pseudalopex } \\
\text { gymnocercus }^{\mathrm{a}}\end{array}$ & Pampas fox & $\begin{array}{l}\text { Eastern Argentina to the Río Negro, eastern Bolivia, } \\
\text { southeastern Brazil, Paraguay, }\end{array}$ \\
\hline $\begin{array}{l}\text { Pseudalopex } \\
\text { sechurae }^{\mathrm{a}}\end{array}$ & Sechuran fox & Coastal deserts of northern Peru and southern Ecuador \\
\hline $\begin{array}{l}\text { Pseudalopex } \\
\text { vetulus }^{\mathrm{a}}\end{array}$ & Hoary fox & South-central Brazil (Minas Gerais and Mato Grosso) \\
\hline Speothos venaticus & Bush dog & $\begin{array}{l}\text { Panama to Guyana, coastal lowlands of Colombia and } \\
\text { Ecuador, Brazil }\end{array}$ \\
\hline $\begin{array}{l}\text { Urocyon } \\
\text { cinereoargenteus }\end{array}$ & Grey fox & Colombia and Venezuela + Central and North America \\
\hline
\end{tabular}

${ }^{\mathrm{a}}$ The genus Pseudalopex has previously often been referred to as Lycalopex or Dusicyon 
suggests that these two lineages may have begun to diverge from one another before either invaded South America (Perini et al. 2010). Early members of the fox radiation occur in the South American fossil record from the late Pliocene, about 2.5 million years ago. The subsequent speciation of Pseudalopex spp. was probably promoted (from around 1.3 million years ago) by the complex climatic changes that marked the late Quaternary of the Andes and southern South America (Markgraf 1993). Along with genera that were related to it but are now extinct, Chrysocyon first appears in the fossil record in the early-to-mid Pleistocene (Prevosti et al. 2005).

A fifth genus of canid also survived in South America until quite recently. Its most recent representative, the so-called Falkland Islands wolf (Dusicyon australis), colonised the Falklands around the Last Glacial Maximum and became extinct in the late 1800s (Austin et al. 2013). A sister taxon, Dusicyon avus, now seems to have survived in Patagonia and on the Argentine Pampas until European contact, although it likely suffered a reduction in range across the Pleistocene-Holocene transition (Prevosti et al. 2015). Collectively, both species of this coyote-sized clade seem to have been most closely related to the maned wolf (Slater et al. 2009). Stahl (2012) has argued convincingly that in some parts of South America people not only tamed some of these endemic canids, but also developed ritual associations with them. Examples include the burial of Sechuran fox (P. sechurae) teeth and jaws with people at the Las Vegas type-site in Ecuador (Stothert 1988), and the inclusion of post-cranial material belonging to the culpeo (P. culpaeus) with human burials at Cueva Baño-Nuevo-1, Chile (Mena et al. 2003). Across the Andes, Prates (2014) reports a comparable instance, the burial of a $D$. avus individual from Loma de los Muertos in northeastern Patagonia. However, the possibility that any South American canid species successfully interbred with the dog, as some nineteenth- and early twentieth-century accounts suggest (Stahl 2012, 2013), has yet to be confirmed by genetic studies. That possibility is, in any case, likely to be extremely remote given the early Pliocene time-depth of the divergence between those species and the genus Canis (Perini et al. 2010, Fig. 4) and the difference in chromosome numbers between South American canids $(\mathrm{N}=74$ or 76$)$ and the $\operatorname{dog}(\mathrm{N}=78)$ (Vilà and Leonard 2001, Fig. 2).

If we wish to ascertain the dog's antiquity in South America we must contend with a number of taphonomic issues. Fragmentary or poorly preserved bones, for example, may make it difficult to unambiguously differentiate its remains from those of the wild canids I have just reviewed; attribution to the former cannot simply be assumed (pace Miller and Gill 1990, p. 54). The enormous size variation produced under domestication complicates this further and, as elsewhere, most identifications are based on the presence of diagnostic teeth, mandibles, or other cranial parts to the exclusion of post-crania (Stahl 2012; but see Loponte and Acosta 2016 for an exception). Identifications employing ancient DNA are still few (but see Leonard et al. 2002; Tito et al. 2011; Thalmann et al. 2013; Witt et al. 2015) and their scope is inevitably limited by preservation biases. It would also be foolish to assume that dogs necessarily died in the locations that archaeologists excavate. While the Americas have produced numerous examples of deliberate canine burials (e.g. Morey 2006) and there is ample ethnographic and historical evidence of people 
eating dogs in some parts of the New World (Schwartz 1997), mortally ill animals often hide themselves away and we cannot assume that people returned the bodies of dogs that died away from home, for example while hunting, to their occupation sites. Finally, as in all assessments of archaeological evidence, we must be sure that the stratigraphic association and date of the remains in question are correct; thus far, only a small minority of dogs has been directly dated using the AMS radiocarbon technique.

With these cautions in mind, Table 2 lists early instances of domestic dogs in the Americas, emphasising their earliest occurrence in each region (Fig. 1). It is immediately obvious that dogs are archaeologically demonstrable much earlier in North America - and specifically in the United States-than they are further south. Within Mesoamerica clay figurines from Tlapacoya are almost certainly several millennia younger than the 5000-6000 years sometimes claimed (Valadez Azúa 1995), while a 9000-7000-year-old age for five dogs buried in association with two people at Cueva del Tecolote in Hidalgo rests solely upon stratigraphic extrapolation and claimed archaeological affinities (Pompa y Padilla and Serrano Carreto 2001), not direct dating. The oldest credible evidence thus comprises dental remains from two sites in the Tehuacán Valley dated no earlier than the Late Archaic Abejas phase (c. 3825-2600 cal. BC (Flannery 1967; Rosenswig 2015, p. 125), with all other finds post-dating 3500 BP (Valadez Azúa et al. 2013). Finds from Panama do not necessarily conflict with this: remains of domestic dog at Aguadulce III are only broadly dated between $>7000$ and $2500 \mathrm{BP}$, while at Cerro Mangote, which is dated to 7000-5000 BP, the attribution given is only to C. cf. familiaris (Cooke et al. 2007; Koster 2009, p. 576). In both Central America and Mesoamerica dogs only become more common from Early and Middle Formative times (post-1600 cal. BC; Cupul-Magaña et al. 2014; Rosenswig 2015). Claims for the dog's terminal Pleistocene/early Holocene presence within South America can also be dismissed. Canid remains pre-dating 8000 BP in the Southern Cone, such as those from Fell's Cave in southern Patagonia (Amorosi and Prevosti 2008), belong to Dusicyon avus or to foxes of the genus Pseudalopex [P. (formerly D.) culpaeus, griseus, and gymnocercus] (Stahl 2012, Table 2). Early Holocene identifications of domestic dogs further north in the Peruvian Andes must also be discounted as the bones in question are only tentatively identified, indirectly dated, or poorly described. These concerns remove from consideration all sites in South America older than around 3000 cal. BC (Larson et al. 2012, Table S2; Stahl 2012, p. 115).

The oldest credible instances of domesticated dogs in South America thus come from two sites in lowland Ecuador, Loma Alta (Stahl 1984) and Real Alto (Salomon and Stahl 2008), plus a third-Huaricanga-in coastal Peru, where coprolites show dogs were fed on maize (Haas et al. 2013). All date to the third millennium cal. BC, with Loma Alta and Huaricanga broadly coeval with the two oldest instances of the dog from south-central Mexico, perhaps suggesting a rapid spread through Central America and into the northwestern corner of South America. However, expansion into the Andes of Peru and Bolivia may have taken longer. More recent evaluations of the dog remains from Rosamachay Cave near Ayacucho emphasise a single mummified burial and place its age at around 2400 cal. BP (Wing 1986), rather than the mid-fourth millennium cal. BC dates reported by MacNeish and Vierra (1983). 


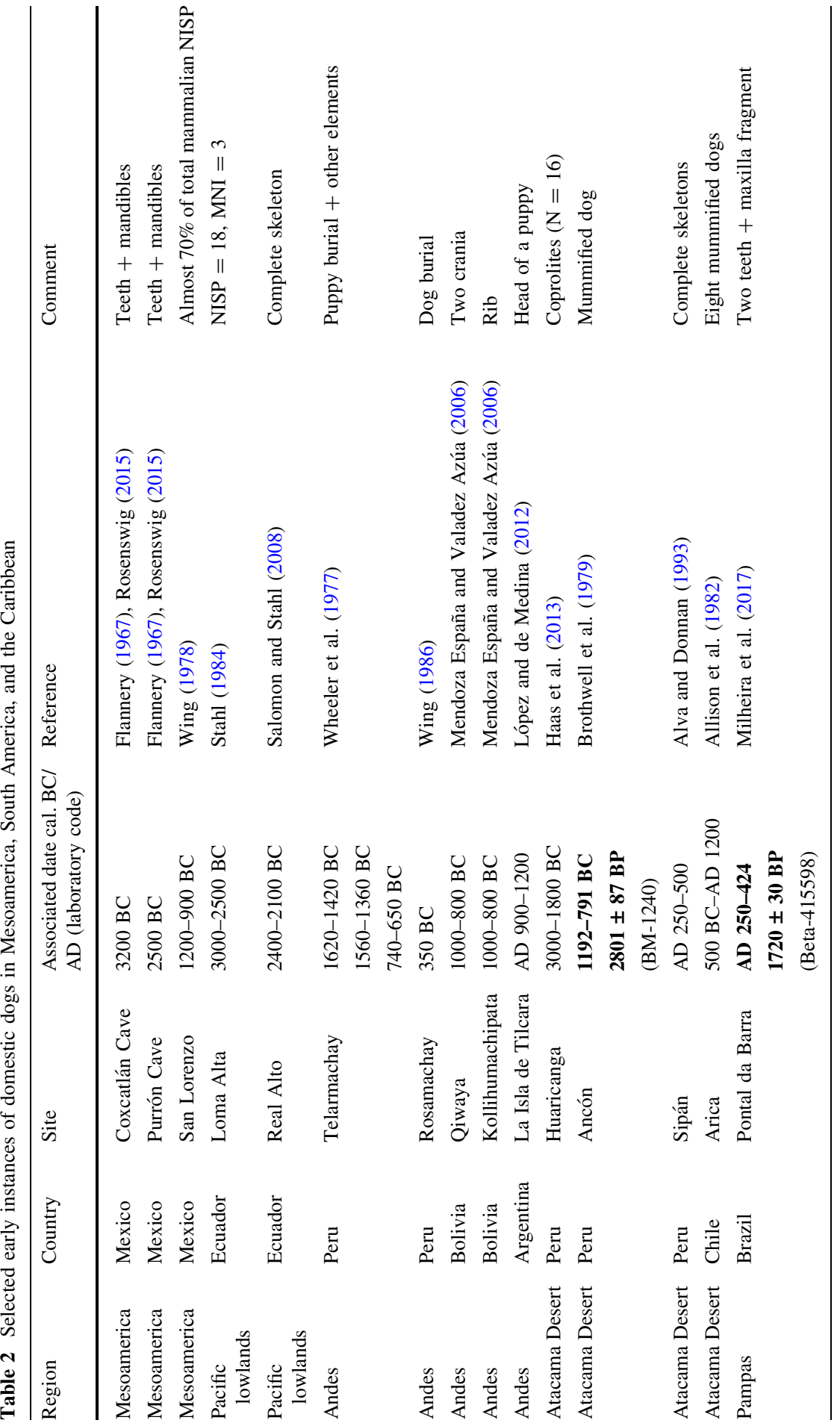




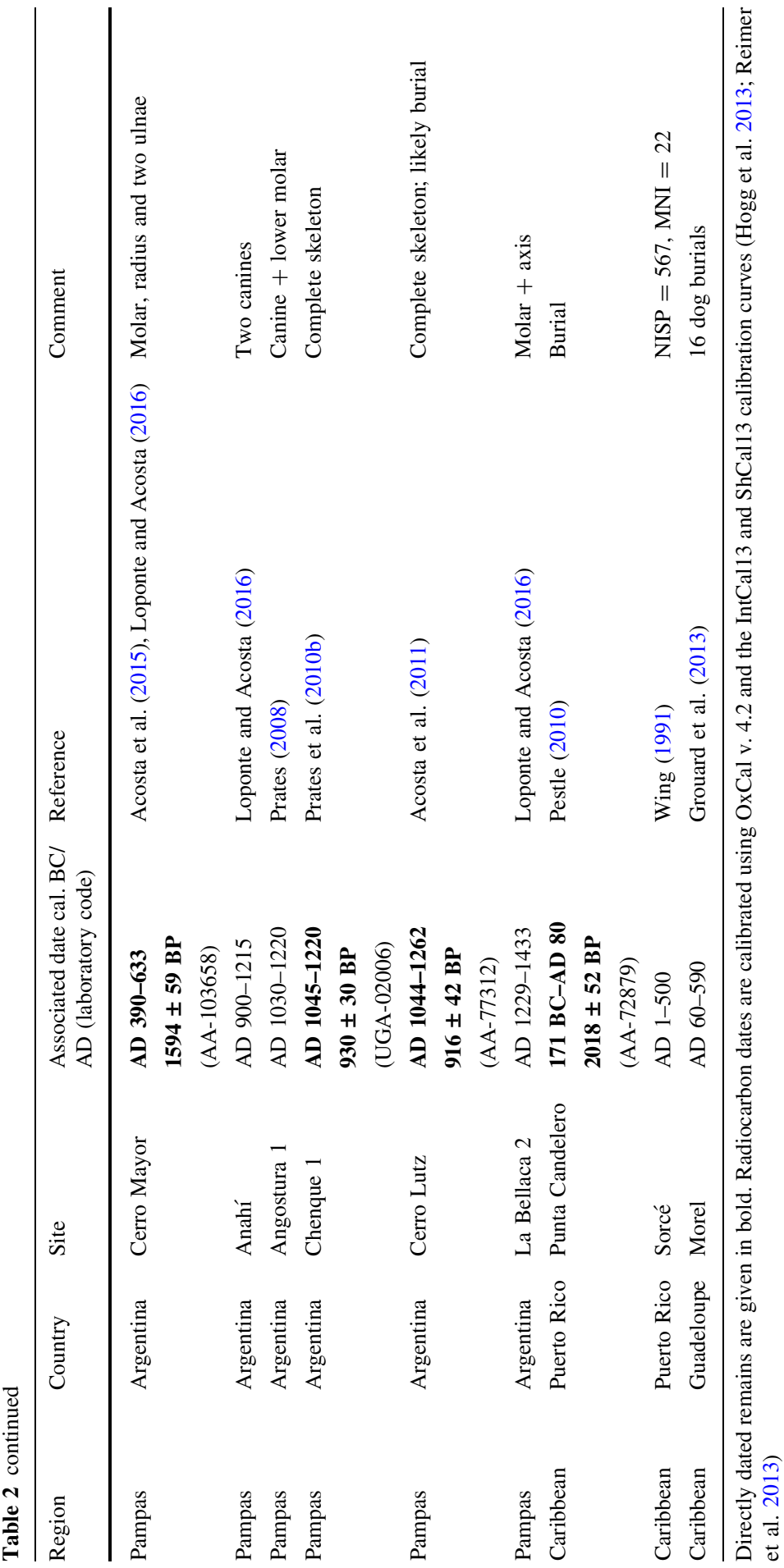




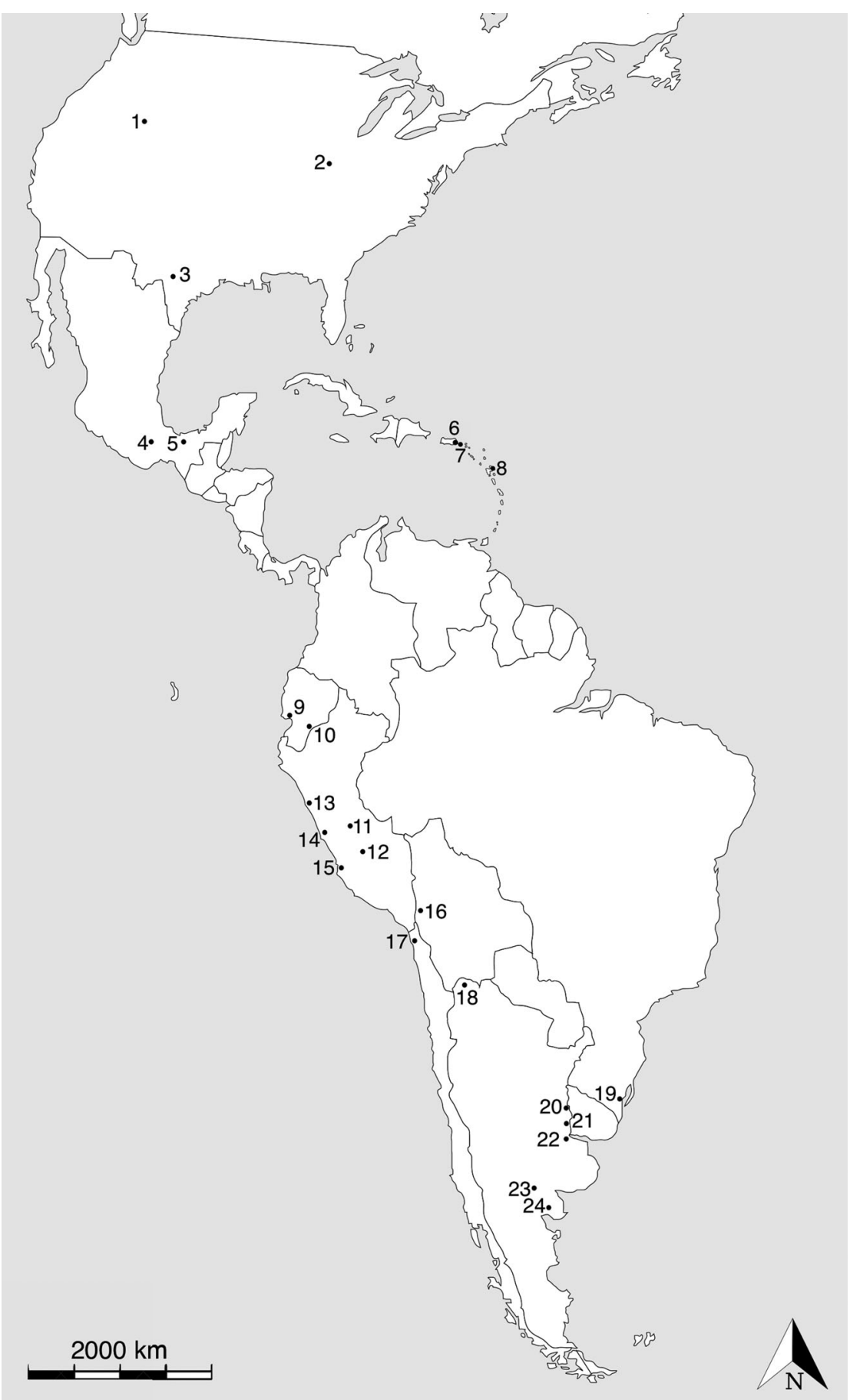


4Fig. 1 The Americas showing sites with early evidence for the presence of domesticated dogs. Sites are numbered as follows: 1 Danger Cave; 2 Koster; 3 Hinds Cave; 4 Coxcatlán Cave and Purrón Cave; 5 San Lorenzo; 6 Punta Candelero; 7 Sorcé; 8 Morel; 9 Real Alto; 10 Loma Alta; 11 Telarmachay; 12 Rosamachay; 13 Sipán; 14 Huaricanga; 15 Ancón; 16 Kollihumachipata and Qiwaya; 17 Arica; 18 La Isla de Tilcara; 19 Pontal da Barra; 20 Cerro Mayor; 21 Cerro Lutz; 22 Anahí and La Bellaca; 23 Chenque 1; 24 Angostura 1

Faunal remains and possible iconographic representations from other highland sites place dogs in the central Andes of Peru and Bolivia only from c. 1500 cal. BC (e.g. Mendoza España and Valadez Azúa 2006), with Ancón near Lima (Brothwell et al. 1979) following soon after. Finds from the Jujuy, Salta, and Catamarca areas of northwestern Argentina principally comprise deliberate burials and are much later in date, mostly from the period when the region was under Inka domination (Berón et al. 2015, p. 43; Prates et al. 2010a; cf. López de Medina 2012, 2016).

Three areas remain to be considered. From north to south they are the Caribbean, Amazonia, and the Southern Cone. Pre-Columbian dogs are most evident in the first, with the oldest examples in Puerto Rico dating to around the time of Christ (Pestle 2010), followed by multiple instances in Saladoid contexts in the Lesser Antilles and the Bahamas in the early centuries cal. AD (Blick et al. 2016). Their presence in the Caribbean is explained as a result of transport by people migrating north from near the mouth of the Orinoco River, who brought with them plants and animals of undoubtedly South American origin (Fitzpatrick 2015; Giovas et al. 2012). Dogs were subsequently widely traded within the Antilles (Laffoon et al. 2015).

On the South American mainland dogs were present in northern Colombia from the first millennium cal. BC (Angulo Váldes 1981; Ardila 1983), and they were presumably also kept further east at the same time to permit their subsequent introduction to the West Indies. In the early centuries of European contact groups like the Trio of the Suriname/French Guiana/Brazil borderlands (Grotti 2013) used dogs to hunt and traded them to others, while hunting alone is also more widely reported from the Guianas and the Orinoco Delta (Gillin 1948, p. 827; Métraux 1948, p. 871), though not on the Venezuelan llanos (Kirchhoff 1948, p. 465). Schwartz's (1997) review of Native American terms for dog likewise suggests a pre-1492 presence in at least parts of the Guianas and the Orinoco Basin. However, their existence elsewhere in lowland South America is much more debatable and, although poor bone preservation must obviously be taken into account, 'the apparent paucity of iconographic evidence of dogs in the region is noteworthy' (Koster 2009, p. 576). Moreover, neither historical nor ethnographic accounts support dogs being in Amazonia, except perhaps on the 'margins of the vast rainforest' (Schwartz 1997, p. 40), before European settlement (Koster 2009, p. 572; Steward 1948; Vander Velden 2008, p. 3). Tellingly, for example, Nimuendaju (1948, p. 247) notes that in the early 1800s the Maué, living southeast of modern Manaus in central Amazonia, 'would refuse any game killed with guns or with dogs, leading one to believe that originally dogs were as foreign to them as fire arms.' Dogs were also apparently absent from the savannahs of the Gran Chaco before European contact (Métraux 1946, pp. 212, 265; Prates et al. 2010a, p. 224). Linguistic evidence concurs, with the word for 'dog' clearly borrowed from Spanish or Portuguese in multiple 
Arawak, Cariban, Macro-Ge, and Tupian languages of the South American lowlands (Pache et al. 2016).

Any dogs found in the countries of the Southern Cone must therefore have derived ultimately from the Andes. Relevant archaeological observations are restricted to a single, newly reported find from Brazil and small numbers from sites in Uruguay and Argentina. The Brazilian example is directly dated to the first half of the first millennium $\mathrm{AD}$ and comes from an artificial mound structure (cerrito) at Pontal da Barra built by complex hunter-gatherers/early food-producers in Brazil's southernmost state, Rio Grande do Sul (Milheira et al. 2017). Immediately to the south in Uruguay dogs from funerary contexts in other cerritos do not have direct dates, making it difficult to be sure what to make of the possibility that they belong to the earlier (first/second millennium BC) contexts claimed for them (Bracco et al. 2000; López Mazz and Castiñera 2001). Articulated canid skeletons at a third site could not be confirmed as belonging to domestic dogs (Rudolph 2014) and Loponte and Acosta (2016, p. 447) remind us that the cerritos are 'complex structures that possess different occupations with distinct chronologies' (my translation), in other words, in the absence of direct dating we should not assume that in such situations the claimed contextual associations are necessarily correct.

We are on firmer ground in Argentina. Here, finds include two complete skeletons deliberately buried in human cemeteries, one at Chenque 1 in the southwestern Pampas, where a dog accompanied a young child (Prates et al. 2010b; Fig. 2) and the other at Cerro Lutz in the east of the lower Río Plata Basin of central eastern Argentina (Acosta et al. 2011). There are also a few teeth from a third site, Angostura 1, in the far north of Patagonia (Prates 2008). All three finds are tightly dated to the first quarter of the second millennium cal. AD. An ulna from a fourth site, Cerro Mayor, located close to Cerro Lutz, is directly dated to the mid first millennium cal. AD. A small number of other remains, most of them examples of dogs' teeth being used as ornaments, have also been reported in this area from other sites dating to the late first/early second millennium AD (Acosta et al. 2015; Loponte and Acosta 2016). All these finds occur in hunter-gatherer contexts that exemplify several processes of social and economic intensification at this time, including increased circulation of people, goods, and ideas, particularly with more complex societies to the northwest, that is, the southeastern edge of the Andean world (Acosta et al. 2011; Loponte et al. 2005; Prates et al. 2010b). Consistent with the possibility that these early Argentine dogs (and those from Uruguay and Rio Grande do Sul?) were of non-local origin, oxygen isotope values for those from two sites in the basin of the Río Paraná (Anahí and La Bellaca 2), both of which date to the early second millennium AD, clearly demonstrate that they had been bred and had grown up elsewhere. An isotopic match with northwestern Argentina has not, however, yet been established, and the similar isotope values of the dogs from Cerro Lutz and Cerro Mayor, which come from the west bank of the Uruguay Valley a little to the north, mean that this area needs also to be considered (Loponte and Acosta 2016). It is nevertheless interesting to note that, unless introduced as adults, the Anahí and La Bellaca 2 dogs did not live long enough after their introduction to the Paraná region to acquire a local isotope signature, raising the question of whether this was because of 'death at the hands of man, or of a lack of adaptation to 


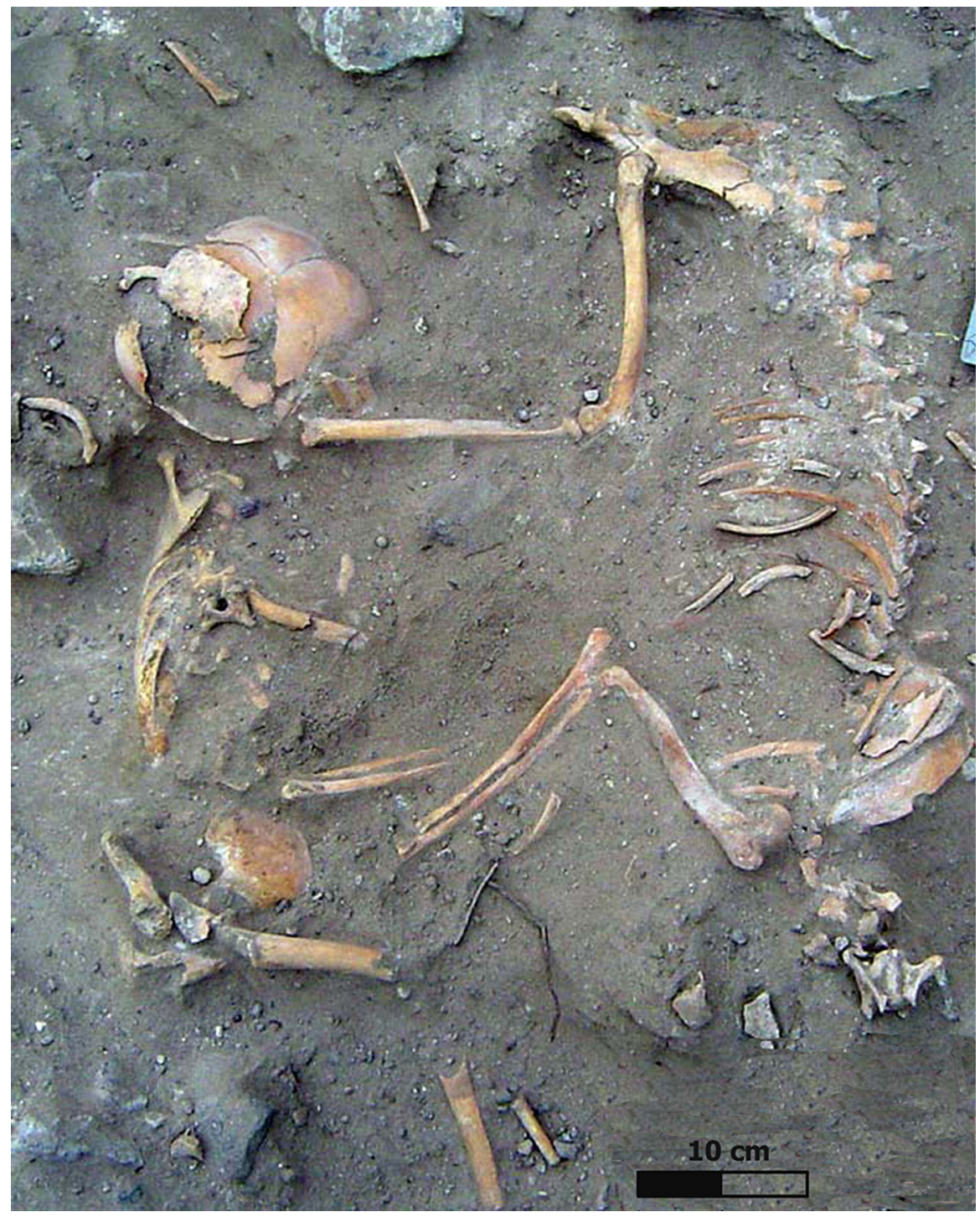

Fig. 2 Remains of a dog (on the right) and a child (on the left) buried together at Chenque 1, Argentina (Prates et al. 2010b). Courtesy of Monica Berón

the environment' in which they now found themselves (Loponte and Acosta 2016, p. 449; my translation).

With one exception from somewhere along the Paraná River (Loponte and Acosta 2016, p. 448), there is a marked lack of sixteenth/seventeenth-century European references to dogs in the northern Patagonian-Pampas region, something that contrasts sharply with the situation in the Andes and the extreme northwest of Argentina. This certainly suggests that dogs remained rare in the Pampas region as a 
whole in pre-Hispanic times (Acosta et al. 2011, p. 190), even if the Pontal da Barra find now pushes back their presence to the early centuries AD (Milheira et al. 2017). Moreover, despite later European observations of their use in hunting guanaco (Lama guanicoe), huemul deer (Hippocamelus bisculcus), and rhea (Rhea spp.) (Fernández and Carballido Calatayud 2015), there is absolutely no signarchaeological or historical-of their presence in central and southern Patagonia or Tierra del Fuego before European arrival (Caviglia 1985/86; Prates et al. 2010a). The dogs kept there by groups such as the Tehuelche (Aónik'enk; Fig. 3), Ona (Selk'nam), and Yahgan (Yamana) in the eighteenth and nineteenth centuries (Schwartz 1997, pp. 43-45) were likely of European origin. Competition from them and from feral individuals (Cabrera 1934) may have contributed to the extinction in early historic times of Dusicyon avus noted earlier (Prevosti et al. 2015).

Where dogs were kept what purposes did they serve? Companionship is certainly one possibility, and may be inferable archaeologically from the presence of dog burials with or without an accompanying human interment, as in the Paracas Culture of coastal southern Peru (Tello and Xesspe 1979) or the approximately contemporary Moche royal graves at Sipán a little further north (Alva and Donnan 1993). Neither in these cases nor in others, however, can religious motivations be excluded, given that at least some South American societies have understood dogs as welcoming or directing the dead into the afterlife (Schwartz 1997, p. 97). More generally, hunting and the deterrence of predators (human as well as animal) were probably the two most common functions that South American dogs served. In the Guianas, for example, groups like the Taruma and Waiwai used dogs to hunt deer

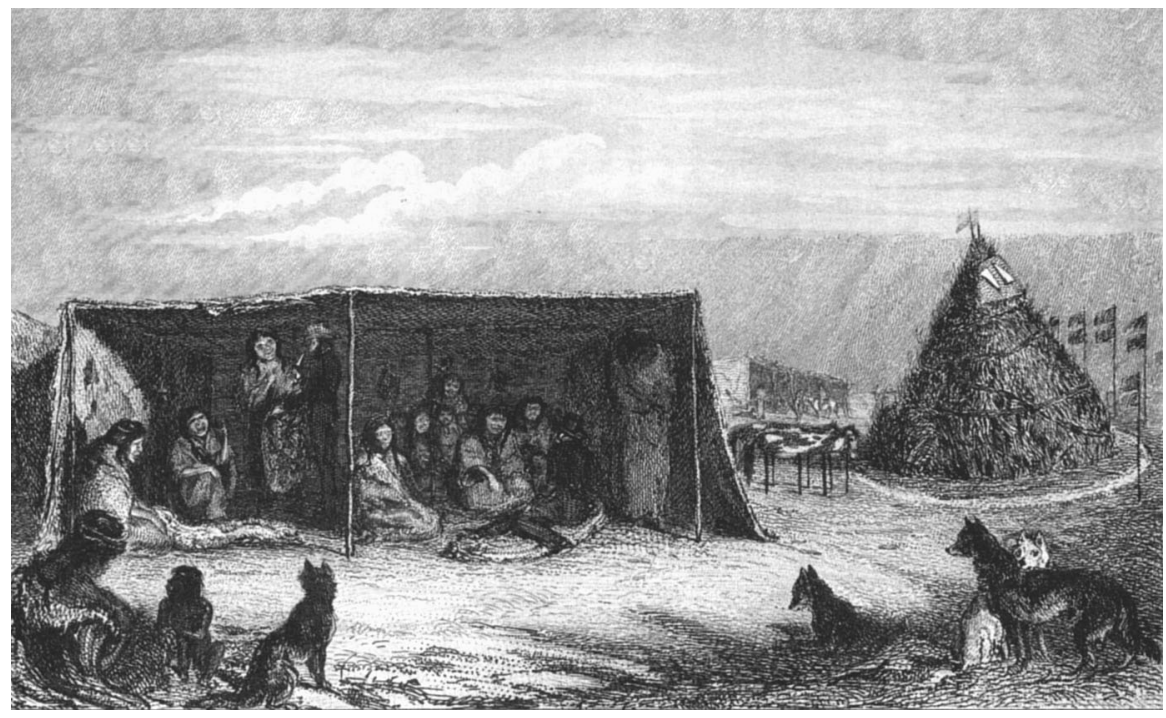

Fig. 3 Dogs were a post-European contact introduction to the Aónik'enk people of Patagonia. Here several stand or sit in front of a typical skin tent (toldo) pitched next to a grave (at far right) marked by two stuffed horse carcasses near San Gregorio, on the north shore of the Strait of Magellan, Chile, in 1827 (King 1839, p. after 94) 
(Odocoileus virginianus), tapir (Tapirus spp.), and peccaries (Tayassuidae) (Farabee 1918; Fock 1963). Further south, the Mapuche of Chile used them to hunt puma (Puma concolor) and 'partridges' (probably Chilean tinamou, Nothoprocta perdicaria) (Cooper 1946a, p. 703), while the Aymara of Bolivia employed dogs to help drive vicuñas (Vicugna vicugna) into surrounds (Tschopik 1946, p. 519). Hunting with dogs was also widely practised where they were introduced after European contact. Examples include Tierra del Fuego, where dogs were used to take foxes and birds (Schwartz 1997, p. 44), Patagonia (as discussed above), and among the now extinct Chono and the still extant Alcaluf (Kaweskar) of southern Chile, who trained them to fish and to hunt otters (Lontra felina) and coypu (Myocastor coypus) (Cooper 1946b, p. 51; Bird 1946, p. 60).

Conversely, and despite the importance in the central Andes of domestic camelids as producers of meat, wool, and dung, there is virtually no record of dogs having been kept to help with herding llamas (Lama glama) or alpacas (Vicugna pacos), at least prior to the Spanish conquest (Schwartz 1997, p. 55), though they may sometimes have helped defend them from predators (e.g. Jesse 1886; but note that neither Bonavia (2008) nor Dransart (2003) mentions this in their respective syntheses). Nor, in sharp contrast with the situation in Mesoamerica where they were widely used as a source of animal protein, is there much evidence that dogs were eaten. Thus, while archaeological faunas do document charred and/or cutmarked dog remains at Loma Alta, Ecuador (Byrd 1976), the much later Moche centre of Pampa Grande, Peru (Shimada and Shimada 1981), and among early second-millennium AD Wanka communities of the Upper Mantaro Valley north of Cuzco (Sandefur 1988), such instances are rare, and ethnographic and historical accounts indicate that dogs were generally not eaten. Other uses were even more marginal: a single reported example, among the Chono of southern Chile, of weaving dog hair to make clothes (Cooper 1946b, p. 52), and an equally isolated instance from the late 1700s of dogs being employed to transport the possessions of one Patagonian group that-tellingly_had lost all its horses (De Viedma 1837, p. 68). From a practical standpoint, then, and while they certainly also featured in ritual and cosmology, where people kept dogs it was primarily as hunting aids and pets, rather than for the more varied uses attested elsewhere in North America or the Old World.

To summarise the argument thus far, relative to their earlier presence in North America dogs appear to have been latecomers to southern Mesoamerica and Central America, first becoming evident archaeologically not long before their appearance in Ecuador c. 3000 cal. BC. Once in South America, what may have been quite a small founding population (Witt et al. 2015, p. 111) seems at first to have been confined to the Pacific lowlands of Ecuador, Peru, and northern Chile and to the central Andes of Bolivia and Peru before dispersing into the Caribbeanpresumably from a Venezuelan source-in the early centuries AD. There is currently no evidence to push back their presence in the far north of the continent before the first millennium $\mathrm{BC}$; published finds are restricted to the lower Magdalena River and the area immediately south of the La Guajira Peninsula.

Further south, dogs were apparently absent from Amazonia in pre-Columbian times, though Stahl (2013) presents evidence for the taming of native South 
American canids, a process also attested for a much wider range of mammals and birds. Beyond the rainforest, dogs entered the grassland regions of Rio Grande do Sul in southeastern Brazil, Uruguay, and central Argentina at best 1500 years before European arrival, but remained rare. This is unlikely to be due to sampling error given the number of archaeological sites investigated (Acosta et al. 2011), but would be consistent with the possibility that the dogs found there so far were introduced via exchange networks from elsewhere, for example northwestern Argentina (Loponte and Acosta 2016). In any event, dogs do not seem to have reached southern and central Patagonia at all; both there and in Tierra del Fuego the first dogs were probably European introductions (pace Cardich et al. 1977). The picture is sketchy and clearly at risk of being skewed by preservation and research biases, but the late entrance of dogs into the Neotropics compared to North America, the slowness with which they expanded beyond the Andean world and its Pacific coasts, and their absence from vast swathes of the continent as late as the sixteenth century stand out. Indeed, the large scale of this patterning, covering highly diverse taphonomic modes and research histories, makes it unlikely that it is biased by sampling limitations. Given that where they do and did occur dogs are-and weretypically highly valued as companions and hunting aids, can disease help account for this patterning and, if so, what diseases might have been involved?

\section{Canine Disease Challenges in South America}

Today, South America presents a wealth of disease challenges to domestic dogs. However, several of these are relatively recent introductions, having arrived only in the aftermath of European invasion in the sixteenth century. In some cases this reflects the arrival of a new pathogen able to take advantage of a range of hosts, including dogs, while in others it reflects the additional arrival of new vectors capable of transmitting the infection to dogs and other animals. An incomplete list of such diseases would include rabies, surra (a trypanosomal disease related to canine [and human] trypanosomiasis), canine babesiosis, and visceral leishmaniasis caused by infection with Leishmania infantum (chagasi). Genetic data sometimes confirm an exotic origin (e.g. Eiras et al. 2008; Leblois et al. 2011). Likewise, although canine monocytic ehrlichiosis is now one of the most important diseases to infect dogs in parts of Brazil (Labruna et al. 2007), not only its pathogen, Ehrlichia canis, but also its vector, the brown dog tick Rhipicephalus sanguineus, are postColumbian introductions (Szabó et al. 2005; Wei et al. 2014). Instead of examining the effects of these recent introductions, however, I turn now to diseases of likely pre-Columbian antiquity.

As I have already observed, the native dogs of the Americas share a recent common ancestry with grey wolves (van Asch et al. 2013; Witt et al. 2015) and can interbreed both with them and with coyotes. Today, the grey wolf's range is restricted by human persecution and habitat loss. Within North America, however, it never occurred south of the Valley of Mexico (Hendricks et al. 2016, Fig. 1) and it was completely absent from Central and South America. Coyotes extended a few hundred kilometres further south: archaeological evidence definitely places them in 
Belize before Columbus, and historical records indicate that they were either already present, or expanded very quickly, as far south as Nicaragua and Costa Rica by the end of the sixteenth century, with further spread occurring during the twentieth century (Hidalgo-Mihart et al. 2004). Like wolves, however, coyotes did not occur in South America. It follows from this that when domestic dogs entered South (and most of Central) America they may have found themselves confronted with wholly novel diseases of which they had no prior experience, even though such diseases may have been hosted by wild canids endemic to those regions (Figs. 4, 5).

To identify what those diseases may have been we can, of course, look for direct evidence in the archaeological record. Richardson et al. (2012), for example, identified a range of parasites in the mummified remains of Chiribaya shepherd dogs from Peru's Atacama Desert, while aDNA has confirmed the presence in preColumbian humans of at least one of the diseases (trypanosomiasis) discussed here (Aufderheide et al. 2004; Lima et al. 2008). More generally, we can use the veterinary literature to identify diseases of likely pre-Columbian antiquity capable of infecting domestic dogs in South America. Acknowledging the uniformitarian assumptions involved, this may suggest where, how, and under what conditions such infections can take place, as well as their consequences. That canid populations are susceptible to novel diseases, some transmitted via domestic dogs, is well attested, and today such infections pose a major threat to the survival of several wild South American canids (Fiorello et al. 2006). However, the transfer of disease is not a one-way process. The four diseases I now discuss find hosts in many wild animals,

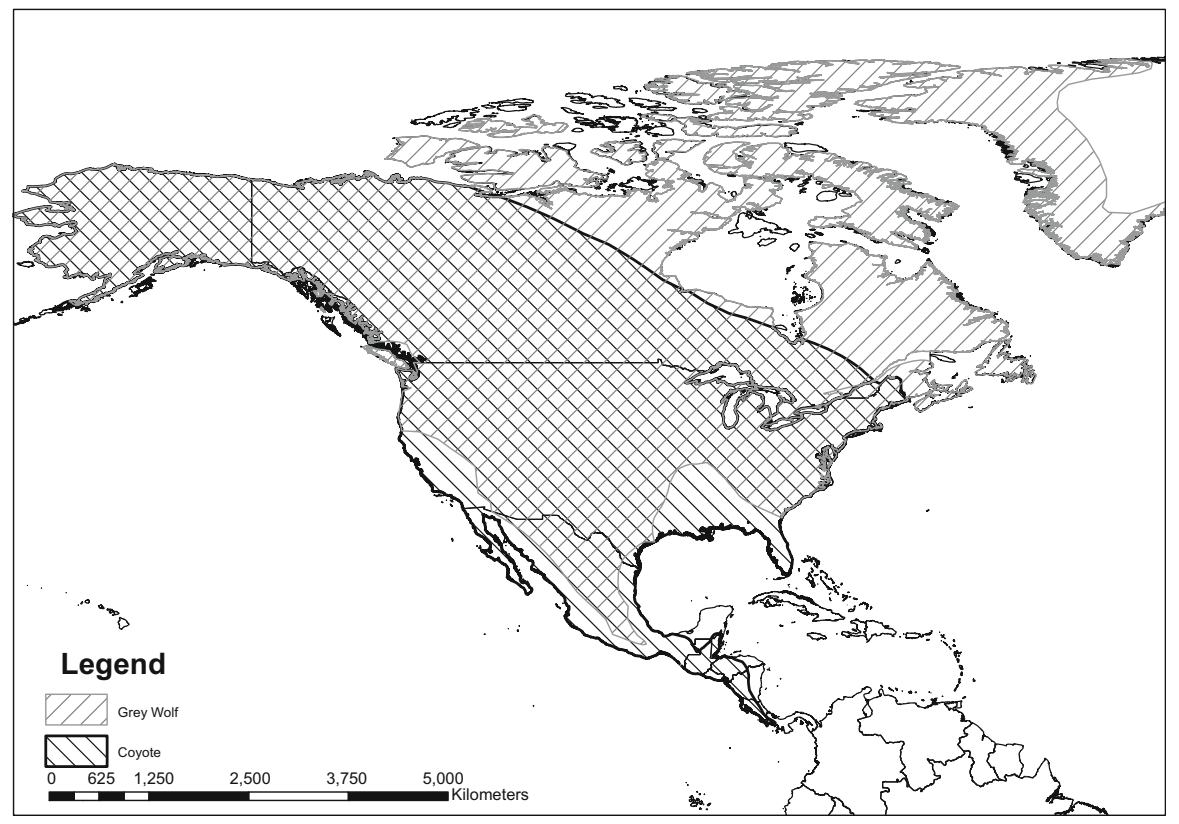

Fig. 4 North America, showing the historical distribution of the grey wolf (Canis lupus) and the coyote (C. latrans) 


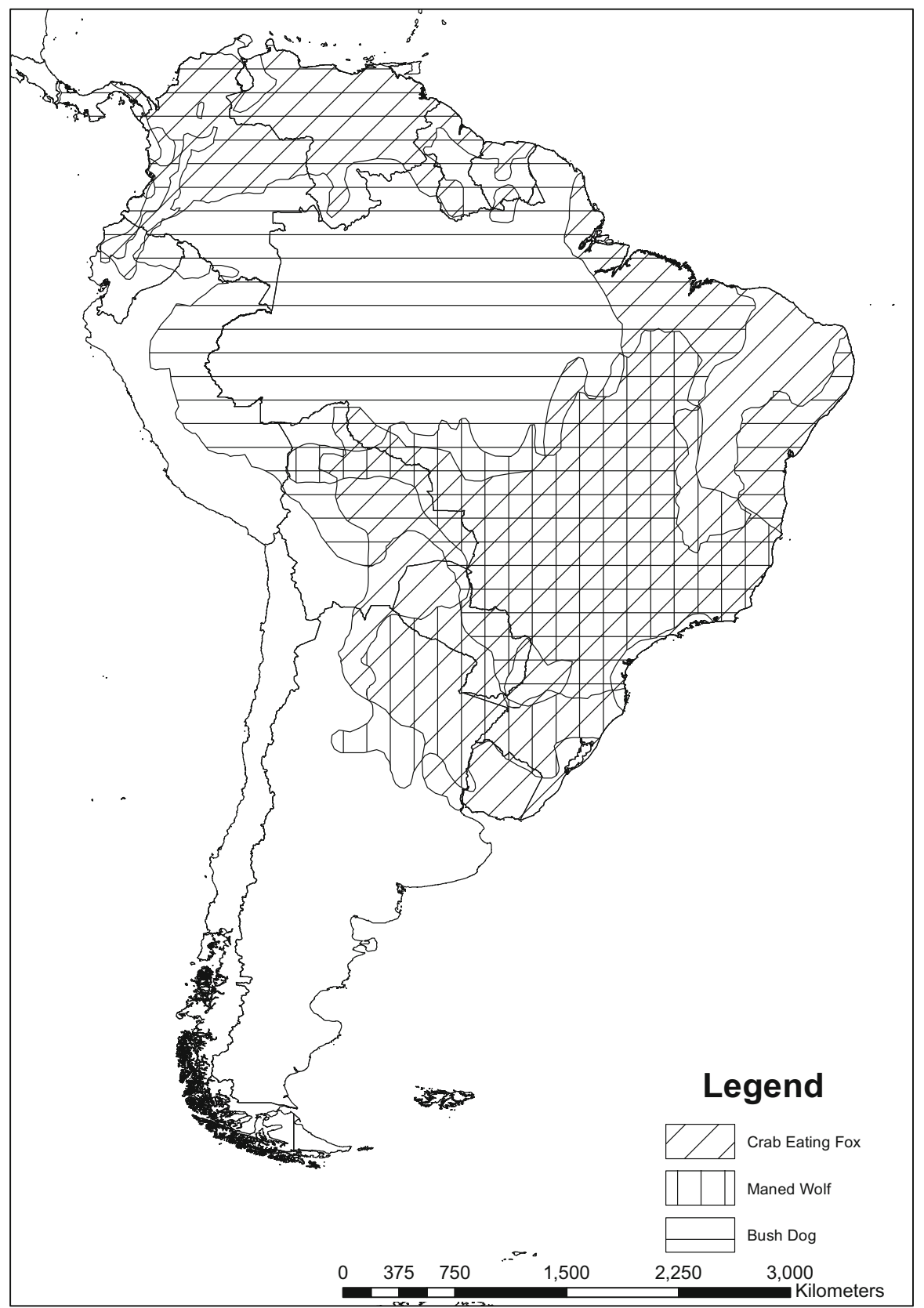

Fig. 5 South America, showing the distribution of three endemic South American canids: bush dogs (Speathos venaticus), crab-eating foxes (Cerdocyon thous), and maned wolves (Chrysocyon brachyurus) 
and dogs are demonstrably susceptible to the ticks and flies that serve as their vectors. As with African livestock (Gifford-Gonzalez 2000, p. 109), the fact that those wild animals show much lower levels of pathogenicity also strongly implies that they have been exposed to these infections for much longer than dogs and that the infections themselves may therefore have posed a serious challenge to dogs on first exposure to them.

\section{Canine Distemper}

Canine distemper is widely recognised as being extremely dangerous, with some assessments identifying it as the most important infectious threat to domestic dogs bar none (Appel and Summers 1999). The pathogen responsible is a virus of the genus Morbillivirus, which is part of the family Paramyxoviridae, and antigenically similar to other well known infectious agents, such as measles and rinderpest. Now occurring worldwide, it is known to infect most terrestrial carnivores, but has also been reported in other mammals, including peccaries and coatis (Nasua spp., Nasuella spp.) in the Neotropics (Headley et al. 2012). The possibility that dogs may act as a reservoir from which the disease can spread into endangered wild canid populations has emerged as a major concern for conservationists in recent decades, not only in Africa (e.g. Alexander and Appel 1994), but also in South America (e.g. Curi et al. 2010).

Once infected with canine distemper dogs exhibit a similar course of infection to humans infected with measles, including fever, rash, and lymphopenia (abnormally low levels of lymphocytes in the blood). A profound suppression of the immune system and generalised depletion of the lymphoid organs marks the acute phase of the disease and there is a high frequency of accompanying neurological complications. The length of the disease's incubation period and its duration and severity vary according to an animal's age and its immune status, as well as the virulence of the particular viral strain involved (Beineke et al. 2015). While anywhere between $50 \%$ and $70 \%$ of infected dogs may remain asymptomatic (Greene and Appel 1990) and survivors retain immunity that is prolonged, or even lifelong (Rosado 2009), distemper's fatality rate is second only to that of rabies (Deem et al. 2000, p. 441). In the late nineteenth century, for example, in several British towns $90 \%$ of affected dogs died (Millais 1890). Even today, distemper remains the principal cause of death in some urban South American dog populations (Fighera et al. 2008) and produces mortality rates of up to $50 \%$ elsewhere (e.g. Alexander and Appel 1994).

Dogs infected with canine distemper virus (CDV) are highly contagious, shedding it for up to 60-90 days after initial infection. Transmission is mainly by direct contact between individual animals, most commonly via infectious aerosols and droplets as the virus is most abundant in respiratory exudates, but it is also present in most body tissues and in urine (Rosado 2009, p. 12). CDV in secretions from wild animals can remain viable for weeks (Greene and Appel 1990), though this varies according to ambient temperature (Deem and Emmons 2000). 
Canine distemper was first described by the Spanish naval explorer Antonio de Ulloa y de la Tore-Giral in 1746 as affecting dogs in the Quito region (and other parts of South America) and was reported soon afterwards in Europe. Recorded in Spain in 1760 - with 900 deaths occurring in a single day in Madrid three years later-it had reached Britain and Italy by 1764 and Russia by 1770 (Blancou 2004). Its ready transmissibility and the greater susceptibility of puppies compared to adult dogs were recognised by Edward Jenner in the early 1800s (Nambulli et al. 2016). Phylogenetic analysis has identified the existence today of 11 distinct strains, 4 of which circulate in South America (Panzera et al. 2014, 2015; Fig. 6). Three are unique to the continent and have been identified in Argentina, Ecuador, and Colombia respectively, while the fourth (EV1/SA1) is known from Argentina, Brazil, and Uruguay, as well as Europe, although 'it is not possible to establish the genetic flow direction between both continents' (Panzera et al. 2014, p. 50). The actual diversity of canine distemper virus in South America may, however, be much greater than this as characterisation studies have so far only been undertaken in five of its thirteen countries (Panzera et al. 2014, p. 51).

Recently, Panzera et al. (2015) have argued that phylogenetic analysis of CDV strains present in a total of 16 countries worldwide indicates a common origin around 125 years ago in the United States, though they admit that their study cannot exclude the disease's existence before then if older strains are now extinct or survive only in unsampled wild hosts. To support their results they cite a suggestion by Bresalier and Worboys (2014) that older historical records refer instead to infections caused by other pathogens, such as the bacteria Pasteurella canis and Bacillus bronchisiptecus. While I am not competent to pass judgement on the attribution of a particular suite of symptoms to any one pathogen, their interpretation is clearly mistaken, as the paper in question does not in fact say this, but merely notes that in seeking a cure or prevention for canine distemper at the beginning of the twentieth century these bacteria were briefly suggested to be responsible for it, something soon ruled out by later research (Bresalier and Worboys 2014, p. 320). As Nambulli et al. (2016, p. 99) comment, any suggestion of a late nineteenth-century North American origin for CDV is indeed 'at variance with the description of the virus in Europe in the 18th century', while the labile nature of CDV's RNA genome means that it is very likely that 'many sequences are lost from the paleovirological record'. The accuracy of current means of calculating the time to the most recent common ancestor (TMRCA) of morbilliviruses is also questionable, since whole genomebased attempts to do this for measles and rinderpest have produced dates in the second millennium $\mathrm{AD}$ that are completely incompatible with the historical record (Nambulli et al. 2016). Dog-related lineages of the rabies virus, for which the most recent common ancestor is estimated to date between AD 1308 and 1510 (Troupin et al. 2016), over 1500 years after the disease was described by Aristotle, are another case in point.

Given these qualifications of Panzera et al.'s (2015) paper, it therefore remains likely that canine distemper was not only first recognised in South America, but also existed there before spreading elsewhere. Is there other evidence to support this? One argument rests on the observation that in Brazil common vampire bats (Desmodus rotundus) contain a virus (DrMV) very closely related to CDV and its 


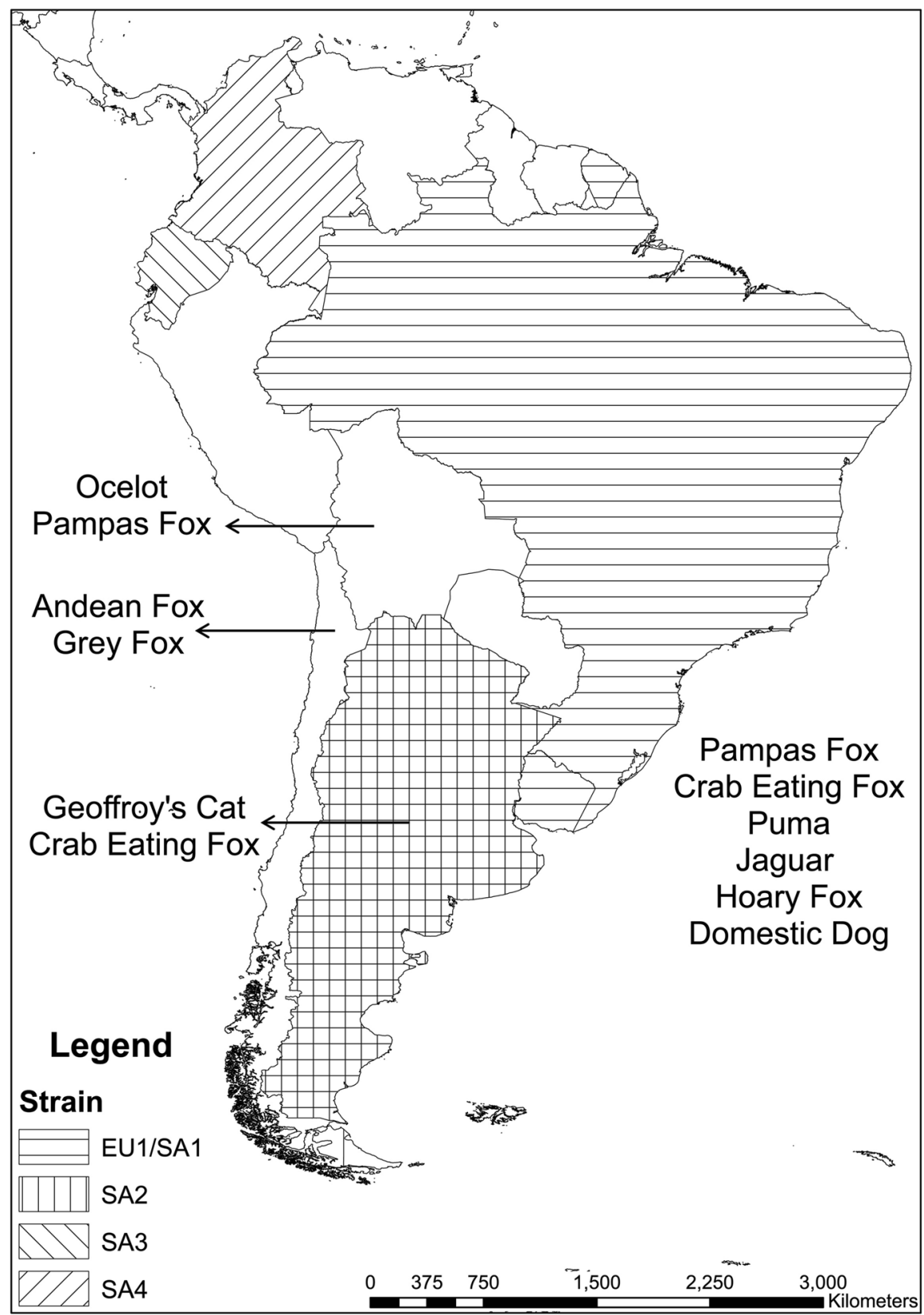

Fig. 6 South America, showing the location of known lineages of canine distemper virus (CDV) and of wild carnivores known to have been infected with it (after Panzera et al. 2014, 2015) 
relative, phocine distemper virus, which infects seals. Because of this 'it is attractive to speculate that CDV and DrMV might share a common South American ancestor' (Nambulli et al. 2016, p. 102; emphasis added).

Further support for this suggestion comes from CDV's presence in other South American animals, including ocelots (Leopardus pardalis) and Pampas foxes (Pseudalopex gymnocercus) in Bolivia (Fiorello et al. 2007) and pumas, jaguars (Panthera onca), kinkajous (Potos flavus), and Geoffroy's cat (Leopardus geoffroyi) elsewhere (Beineke et al. 2015). Although some seroepidemiological surveys have not detected CDV among wild canids (Courtenay et al. 2001; Curi et al. 2010), Megid et al. (2009) report naturally occurring instances of infection in hoary foxes and crab-eating foxes in the south of Brazil. Fatalities have been recorded in both species (Ferreyra et al. 2009; Megid et al. 2010), as well as in Pampas foxes (Giannitti et al. 2012) and grey foxes and culpeos (Acosta-Jarnett et al. 2011). Maned wolves and bush dogs, on the other hand, appear to be immune in the wild, although serological evidence of exposure to CDV exists for the former species (Curi et al. 2012; Deem et al. 2000) and distemper has been induced in them experimentally (McInnes et al. 1992; Thomas-Baker 1985). Summarising this evidence, CDV has long been present in South America, is (and likely was) hosted there by a range of wild carnivores, and could have spread from them into dogs. Spillover in the reverse direction is now rightly feared as a major conservation threat to wild canids (Curi et al. 2010), but the mechanisms involved-genetic proximity and scent-based communication involving contact with infected faeces and urine-can surely work in both directions. Canine distemper, in other words, likely posed a major threat to dogs in South America in pre-Columbian times.

\section{Canine Trypanosomiasis}

The second disease I discuss, canine trypanosomiasis, takes two forms. One, caused by the African parasites Trypanosoma brucei brucei and T. congolense, is an extremely serious threat to dogs in sub-Saharan Africa, while infection by the closely related parasite $T$. evansi is also frequently fatal (Mitchell 2015). Having arrived there as part of the Columbian Exchange, T. evansi now poses a threat to canine health in South America too, but that continent's dogs suffer additionally from a further trypanosomal infection caused by Trypanosoma cruzi. As well as being important to veterinarians and dog-owners, T. cruzi has attracted considerably wider attention since it also affects people, producing a form of trypanosomiasis known as Chagas disease. This currently affects some 16-18 million people in Central and South America, principally in rural and poorer urban areas (Eloy and Lucheis 2009), and is increasingly establishing itself in North America (Hotez et al. 2013). Archaeological evidence recovered from artificially or naturally mummified human remains in the Atacama Desert (Aufderheide et al. 2004), Brazil (Lima et al. 2008), and Texas (Reinhard and Araújo 2015) demonstrates that it has infected humans for at least 9000 years. The antiquity of some of these finds establishes that sedentism and the associations it produced between people and commensal rodents 
or-in the Andes-domesticated guinea pigs (Cavia porcellus) were not necessary for human infection (Ferreira et al. 2011).

Trypanosoma cruzi is found today in some 150 Neotropical mammals, including marsupials, carnivores, primates, bats, rodents, and armadillos (Aguilar et al. 2007). Both crab-eating foxes and maned wolves are among the animals that can become infected (Rocha et al. 2011), but do not show high levels of parasitaemia (i.e. large numbers of parasites in the blood and thus evidence of a serious active infection) (Rocha et al. 2013a, b). The disease is mainly transmitted by the faeces of haematophagous triatomine insects (sometimes known as 'kissing bugs'), which enters the body through a wound or because a person or animal scratches at the site of a bite's irritation (Eloy and Lucheis 2009); oral transmission via contaminated food and drink is also possible (e.g. Nobrega et al. 2009). At least 25 triatomine species distributed among nine genera have been recorded as vectors. Only one, Triatoma infestans, is a major house-dwelling insect, and the principal source of domestic infections in people, with domestic animals, including dogs, its hosts (Aguilar et al. 2007). The remaining sylvatic vectors principally maintain the parasite in its wild hosts, hiding in animal lairs or nests and emerging to feed on their blood when the animal is asleep. However, they can also fly into homes, establishing contact with people or contaminating their food, a possibility currently increasing as a result of extensive deforestation, loss of wild vertebrate populations, and immigration into previously forested areas. In addition, vampire bats can spread the parasite as they feed, and the predation of infected mammals may provide another means of infection (Maywald et al. 1996). Dogs are exposed to infection from biting insects and bats at night, by ingesting the vectors (especially when puppies; Pineda et al. 2011)—which is a highly efficient transmission route-and via hunting infected small mammals such as rodents and marsupials (Herrera et al. 2011). Field studies show a wide range of infection rates, with most falling in the range 8\%-28\% (Eloy and Lucheis 2009, p. 593).

Dogs infected with $T$. cruzi display both acute and chronic forms of trypanosomiasis. In the acute phase major symptoms include extensive lesions, mostly in the myocardium and the central nervous system, accompanied by anorexia, generalised lymphadenopathy (disease of the lymph nodes), diarrhoea, myocarditis, and sudden death, which can occur because of cardiac arrhythmia (Eloy and Lucheis 2009). Lethargy and respiratory difficulties are also noted (Kjos et al. 2008). The chronic phase develops 8-36 months after initial infection and is characterised by ventricular arrhythmias, myocardial dilation, and increased cardiac inefficiency and dysfunction (Eloy and Lucheis 2009).

Chagas disease is now increasingly recognised as a severe health risk to previously unexposed dogs, in part due to its increasing incidence in the southern United States, where opossums (Didelphis virginiana), wood rats (Neotroma cinerea), racoons (Procyon lotor), armadillos (Dasypus novemcinctus), and coyotes are also infected. A study of over 500 serologically and/or histopathologically confirmed cases in Texas dating to between 1993 and 2006 showed that approximately half occurred in animals under one year old, that acute (i.e. rapid) death was the predominant clinical presentation in some $42 \%$ of the 93 histopathologically confirmed incidents, and that this was slightly more common 
in animals under one year old than in those that were older (Kjos et al. 2008). Experimental work confirms the disease's serious nature. In one study, conducted on puppies under four months old, at least 11 out of 26 animals (42\%) infected with blood trypomastigotes (i.e. one of the parasite's developmental stages) and 26 out of 38 animals $(68 \%)$ infected with metacyclic trypomastigotes died during the acute phase, that is, within 50 days of infection (De Lana et al. 1992). In another, Andrade et al. (1984, p. 94) demonstrated 'high mortality' approximately 3 weeks after infection, with all dogs exhibiting severe myocarditis during the acute phase. More recently, Quijano-Hernández et al. (2012) have reported sudden death and mortality rates of 25\%-33\% (depending on dose) within 36 days of infection. In a second study $50 \%$ of unvaccinated dogs died within 5-10 weeks of being infected, with one-third of those vaccinated before infection dying within this time, along with a fifth of those that received a vaccine therapeutically after infection (QuijanoHernández et al. 2013).

Because many wild species show little or no effect from infection with $T$. cruzi the disease is likely to be of considerable antiquity (Aufderheide et al. 2004, p. 2036). Phylogenetic analysis points to its ancestor being a bat trypanosome that probably entered South America some 7-10 million years ago. Various trypanosomal lineages then switched into terrestrial mammals, with $T$. cruzi evolving during the Pliocene (Steverding 2014). Opossums and armadillos, important reservoirs of infection throughout the Americas, were probably among its first hosts (Bern et al. 2011, p. 663). Six distinct lineages (or Discrete Typing Units) are now recognised, with variable distributions through the Americas (Bern et al. 2011). Canine infections in southern South America are principally associated with the TcIV, V, and VI lineages, while those in the north are associated with genotypes Ia and Ib, otherwise known from the southern Andes and northern Argentina (Guhl and Ramírez 2011, p. 3; Fig. 7). Crucially, different lineages may carry variable health implications for people (Macedo and Pena 1998) and probably also for dogs (Duz et al. 2014), something that opens up the possibility that dogs could evolve a degree of resistance to one strain in one region, while remaining exposed to others there or elsewhere. Canine trypanosomiasis in Africa reveals precisely this situation, especially with regard to $T$. congolense and when comparing native African dogs to those introduced to the continent from Europe (Mitchell 2015). The combined weight of observational and experimental evidence indicates that canine Chagas disease continues to pose a major disease challenge to dogs in the Americas and that they have probably been exposed to it since their arrival in the Neotropics.

\section{Canine Rangeliosis}

My third example concerns canine rangeliosis. Popularly referred to as nambiuvú (meaning 'bloody ears'), peste de sangua ('bleeding plague'), and febre amarela dos cães ('dog yellow fever'), this disease was first described in southern and southeastern Brazil in the early 1900s (Franca et al. 2014). More recently, it has also been recognised in northeastern Argentina and Uruguay, but it may be even more widespread than this, albeit undiagnosed elsewhere (Eiras et al. 2014, p. 732). The 


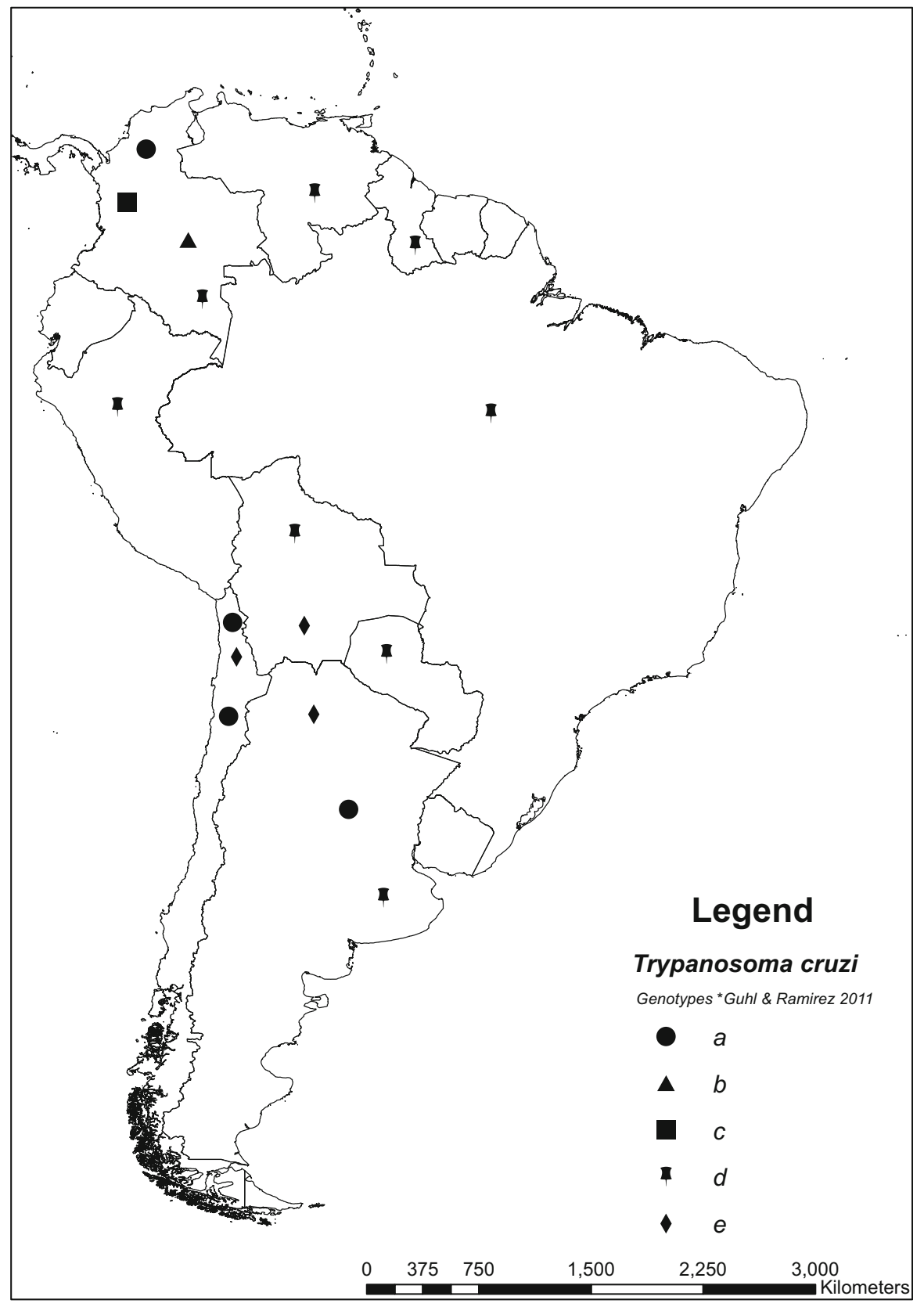

Fig. 7 South America, showing the location of Trypanosoma cruzi I genotypes (after Guhl and Ramírez 2011) 
disease is caused by infection with Rangelia vitalii, a large piroplasm transmitted by the ixodid ticks Amblyomma aureolatum and Rhipicephalus sanguineus (the latter introduced from sub-Saharan Africa). Clinical symptoms appear in natural infections a few days to three months after infection, but in experimentally infected dogs are observed 5-15 days after inoculation. They include fever, anaemia, jaundice, splenomegaly, lymphadenomegaly (enlargement of the lymph nodes), haemorrhage of the gastrointestinal tract, and persistent bleeding from the nose, earlobes, and mouth. Affecting young dogs much more frequently than adults, the disease is normally severe and fatal if not treated appropriately and in good time. Experimentally, animals infected with blood from dogs suffering from the disease die within 1 week of symptoms first appearing (Franca et al. 2010).

Genetic analyses confirm that the organism responsible for canine rangeliosis belongs to a separate genus than the better-known pathogens of the genera Babesia and Theileria, consistent with differences in their lifecycles and the clinical symptoms that they produce (Eiras et al. 2014). As a result of almost a century of scientific neglect, precise details of the disease's life history remain to be worked out (Franca et al. 2014). However, wild animals are thought to act as a reservoir in Brazil (Loretti and Barros 2005). Several South American mammals can be infested by Amblyomma aureolatum ticks, the native vector of $R$. vitalii, not only in the areas from which canine rangeliosis has been reported, but also in several other South American countries (Franca et al. 2014, p. 469). However, so far only crab-eating foxes (Cerdocyon thous) have definitely been identified as a potential reservoir: their infection by $R$. vitalii does not appear to produce any clinical, biochemical, or haematological alterations, indicating that it is significantly less pathogenic in them than in dogs (Soares et al. 2014). As yet, isolated reports of infection of maned wolves (Silveira et al. 2016) and Pampas foxes (de Quadros et al. 2015) relate to individuals that were also severely infected with other parasites, making it difficult to be sure of the specific effects in them of $R$. vitalii.

C. thous is widely distributed in South America, from northern Argentina through Brazil and lowland Bolivia (excluding the Amazon) and on into Venezuela, Colombia, Guyana, and Suriname (Fig. 8). Data on piroplasmid infection of other South American canids are very scarce and it is therefore unclear if they too act as reservoirs capable of transmitting Rangelia vitalii to domestic dogs (Soares et al. 2014). The contrast between high pathogenicity in dogs and its absence in wild canids is, however, paralleled in Africa, where the highly virulent and frequently life-threatening piroplasmid Babesia rossi produces no overt clinical signs in African hunting dogs, black-backed jackals, or golden jackals (Penzhorn 2011), something that is supported by experimental innoculation for at least the first two species (van Heerden 1980). Experimental intravenous infection of dogs with blood and bone marrow samples from $C$. thous has likewise transmitted the disease successfully to previously healthy animals (Soares et al. 2014). Putting all this information together, and noting both the relatively recent date of the dog's introduction to South America and the fact that this is the only piroplasmid agent infecting dogs there not to have been reported outside the continent, 'one would expect that $R$. vitalii would have coevolved with a native canid in South America' (Soares et al. 2014, p. 161). More specifically, it seems reasonable to conclude that 


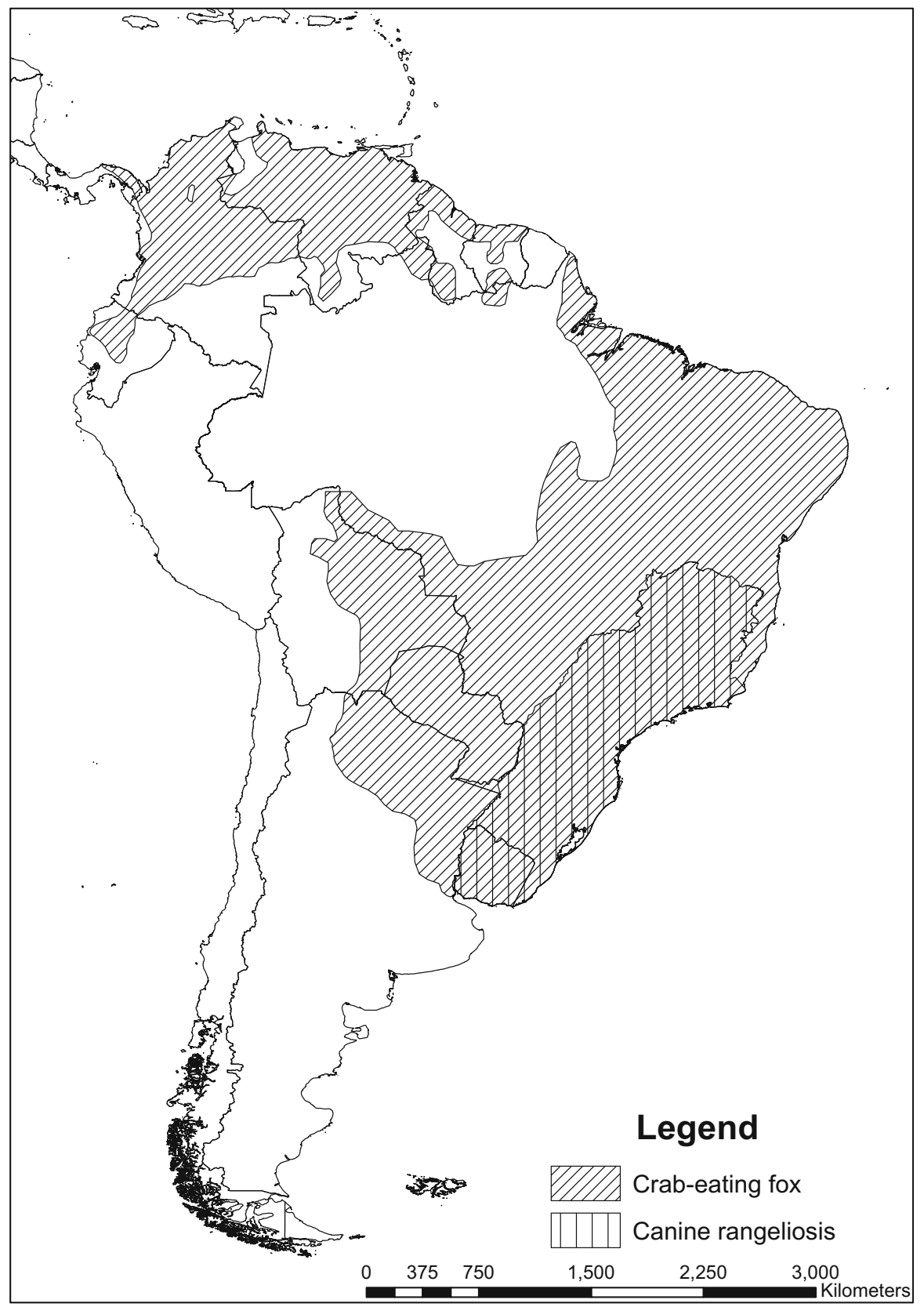

Fig. 8 South America, showing the approximate distribution of the incidence of canine rangeliosis and of the crab-eating fox (Cerdocyon thous) 
canine rangeliosis may have spilt over into dogs from their cousin, the crab-eating fox, and, perhaps, other South American canids as well.

\section{Visceral Leishmaniasis}

The final disease I consider is visceral leishmaniasis (Steverding 2017). Like Chagas disease, it is of major zoonotic concern since Leishmania parasites can also infect people. The best known is L. infantum (previously known as L. chagasi), which was introduced to the Americas after 1492 (Leblois et al. 2011). Like other species of the same genus, it is a diphasic protozoan belonging to the same family as the pathogens responsible for trypanosomiasis in both people and other animals, the Trypanosomatidae. Worldwide, up to 1.2 million new cases of the less serious cutaneous form of leishmaniasis infection, and as many as 400,000 new cases of the more dangerous visceral form, are diagnosed in people each year (Stockdale and Newton 2013). As one of the parasite's principal hosts, dogs play an important part in the disease's transmission, including to people. This may be recognised by some Indigenous groups, such as the Karitiana of Brazilian Amazonia, who consider dogs to be transmitters of skin diseases (Vander Velden 2010, p. 137), something that should make us consider whether human health concerns may even have led people to reject keeping dogs (cf. Mitchell 2015, p. 117 for a similar possibility with respect to visceral leishmaniasis among some groups in Sudan and South Sudan).

Unlike people, dogs may present the cutaneous and visceral forms of leishmaniasis simultaneously as well as separately, although for them the disease is often more of a chronic than an acute condition. Common clinical signs include lethargy, weight loss, anaemia, spleen enlargement, damage to the lymph system, and epitaxis (bleeding from the nose), as well as skin and ocular lesions. Death rates are normally low. However, visceral leishmaniasis can be life threatening, albeit 'not uniformly fatal' (Dantas-Torres et al. 2012, p. 535), as a result of the parasite multiplying and migrating from the lymph tissues to other organs under conditions of immunodeficiency (Andrade and Melo 2015, p. 198). In addition to acquiring the disease from sandflies, dogs may also become infected transplacentally from mother to offspring and-at least under experimental conditions-venereally, by bites, and from licking another animal's wounds, though cases of such horizontal transmission are probably rare (Center for Food Security and Public Health 2009). Asymptomatic dogs are easily infective to sandflies under experimental conditions, helping to maintain high levels of infection within a population.

Today, L. infantum is the most important agent of canine leishmaniasis in South America and has also been held responsible for the deaths of captive wild canids, although free-ranging animals are usually asymptomatic; the stress of confinement, along with changes in diet, altered behaviour, and exposure to infection from nearby commensal hosts, all need to be considered (Luppi et al. 2008). Up to 70 species of Lutzomyia sandflies are suspected of being implicated in the parasite's transmission, but the only well established vector is L. longipalpis (Dantas-Torres 2009). The flies can colonise a wide range of habitats, including primary forest and areas disturbed or altered by human occupation, and can develop year-round. 
At least 14 other Leishmania species are endemic to Central and South America, all spread by Lutzomyia spp. (Cantacessi et al. 2015; Dantas-Torres and Otranto 2014). Some must have infected people in pre-Columbian times based on osteological (Enciso et al. 2001), immunological (Frías et al. 2013), and other palaeopathological data (Costa Junqueira et al. 2009; Marsteller et al. 2011), the recovery of ceramics showing human faces disfigured by what looks like mucocutaneous leishmaniasis (which is restricted to Latin America), and sixteenth-century Spanish descriptions of the disease, though comparable evidence of the almost always fatal visceral form is understandably lacking (Lainson 2012). As well as $L$. infantum, two native species, in particular, 'deserve greater attention' with regard to canine leishmaniasis (Dantas-Torres 2009, p. 6). Both can produce the more dangerous, visceral form of the disease (Fig. 9). L. amazonensis occurs in Argentina, Bolivia, Brazil, French Guiana, Colombia, Ecuador, Peru, Suriname, and Venezuela and has been responsible for cases of visceral leishmaniasis in Brazil (Tolezano et al. 2007). A related taxon, Endotrypanum colombiensis (formerly $L$. colombiensis; Espinosa et al. 2016), which has produced cases in Venezuela, has a more restricted distribution there and in Colombia and Panama (Cantacessi et al. 2015), though it probably also extends into the forests of Brazil and the Peruvian lowlands (Lainson 2012, p. 25). L. amazonensis is known to have a very wide range of hosts, including marsupials, lesser anteaters (Tamandua tetradactyla), rodents, bats, spider monkeys (Ateles paniscus), and carnivores (including crab-eating foxes), while the principal (perhaps only) host of E. colombiensis is Hoffman's twotoed sloth (Choloepus hoffmanni) (Roque and Jansen 2014). As with the other diseases I have discussed, this wide range of hosts indicates that visceral leishmaniasis resulting from infection by these two parasites-and the cutaneous form of the same disease following infection by L. braziliensis, L. guyanensis, $L$. mexicana, L. panamensis, L. peruviana, and L. pifanoi (Cantacessi et al. 2015)was established in Neotropical America long before dogs entered the region (Steverding 2017).

\section{Discussion}

All four of the diseases I have discussed present very real health issues to dogs living in South America today. Canine trypanosomiasis caused by infection with Trypanosoma cruzi has also now become a serious problem in Central America and southern North America, while canine distemper virus is a globally distributed threat. Based on genetic evidence and their existence with few or no obvious symptoms in a range of native South American mammals, all four diseases probably have a South American origin. Relevant animals include bush dogs for canine distemper, maned wolves for canine distemper and canine trypanosomiasis, and crab-eating foxes for canine rangeliosis, canine trypanosomiasis, and canine leishmaniasis. Along with other hosts and relevant insect vectors, these wild canids likely provided the basis for the diseases I have discussed to spill over into domestic dogs after they arrived in South America. Archaeological data suggest that this was late relative to their presence in North America. Furthermore, the dog's subsequent 


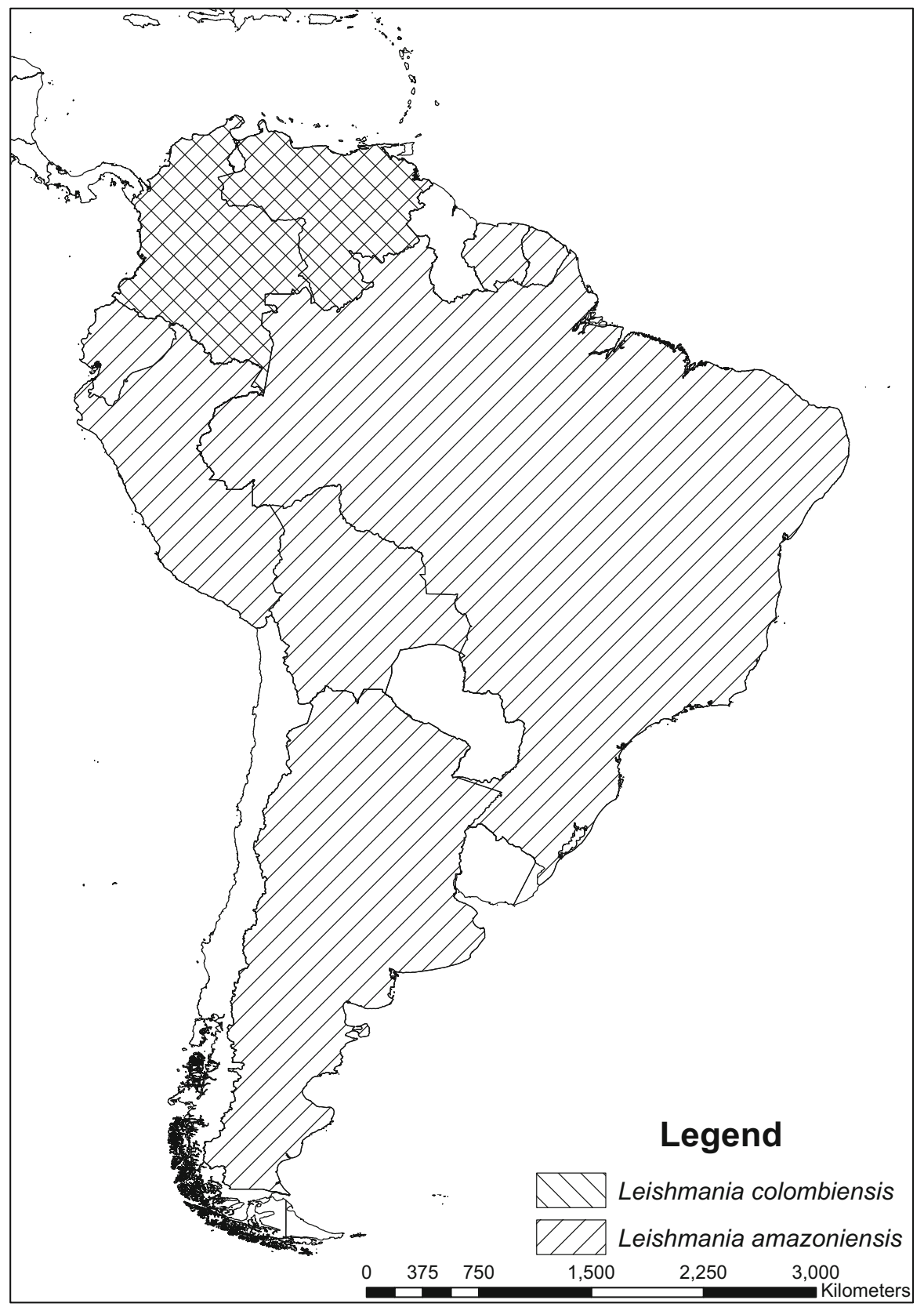

Fig. 9 South America, showing countries associated with endemic species of Leishmania sp. identified as being responsible for cases of canine visceral leishmaniasis (after Roque and Jansen 2014) 
expansion within South America after its first appearance on the coast of Ecuador and Peru was decidedly uneven, with late and limited entry into the northern part of the Southern Cone and a complete absence from all but the western and northern fringes of Amazonia at the time of European contact.

Previous consideration of these lacunae has emphasised the Amazon Basin and has singled out three principal factors to explain the dog's absence there. Stahl $(2012,2014)$ has argued that it may relate to the more general lack of animal domestication in this region, notwithstanding the presence of some potential domesticates such as peccaries and the widespread practice of keeping wild animals, including canids (Stahl 2013), as pets. The argument that Native Amazonian ontologies excluded domestication because the animals that people kept were defined as kin and could not therefore be eaten, while game - and human enemieshad to be predated is well known (e.g. Descola 2001). Additionally, it may indeed be appropriate to think in Amazonia not so much of domesticated species as of domesticated-that is, anthropogenically altered-landscapes (Erickson 2006). Nevertheless, Stahl's argument does not really help us with the dog, which today, as in the recent past, is not eaten or hunted, but is instead of benefit as a hunting aid, guard, and companion. Even if we follow Vander Velden (2008) and accept that for some (many? all?) Amazonian groups dogs have been conceptually associated with jaguars and, as predators, cannot therefore readily enter human societies, we are confronted with the fact that Antillean societies of ultimately Amazonian derivation did keep dogs, just like their ancestors/cousins in Venezuela and the Guianas, who also shared aspects of their worldview with communities in Amazonia.

Taking a different tack, Jeremy Koster (2009) has examined the dog's absence until very recent times from Amazonia primarily from the perspective of its likely utility in hunting (Fig. 10). His own fieldwork in Nicaragua and observations elsewhere suggest that the dog's principal role in Neotropical forests is not to kill prey, but rather to detect it and flush it into locations such as burrows, waterways, and hollow tree trunks where hunters can more easily kill it. In the Bosawas Reserve of Nicaragua, for example, dogs contribute to $86 \%$ of all mammal kills and to more than half of those of iguanas (Iguana iguana), and are particularly effective against agouti (Dasyprocta spp.) (Koster 2008a). Moreover, nocturnally active species like paca (Cuniculus spp.) and nine-banded armadillo (Dasypus novemcinctus) are normally encountered in daytime only when dogs are used (Koster 2008b). That said, dogs appear to be of limited use against white-lipped peccary (Tayassu peccari) (Peres 1996; but cf. De Souza-Mazurek et al. 2000) and perhaps tapir (Koster 2009). They may also be understandably of less value if the focus is on arboreal species (primates, birds) taken with projectile weapons like blowpipes or bows-and-arrows, though note that Veddah hunters in Sri Lanka are known to have used dogs to concentrate monkeys in small groups of trees (Patrick Roberts, pers. comm., 6 June 2016). However, while 'there are few settings in which dogs cannot be at least moderately useful in hunting' (Koster 2009, p. 577), the anti-predator behaviour of prey animals and prey population density are both likely to affect their utility (Koster 2009, pp. 583-587), and in forest areas differences may be expected between várzea, alluvial, and terra firme forests (Peres 2000). Add in their roles as pets or as watchdogs against human raiders and jaguars and it is clear that multiple 


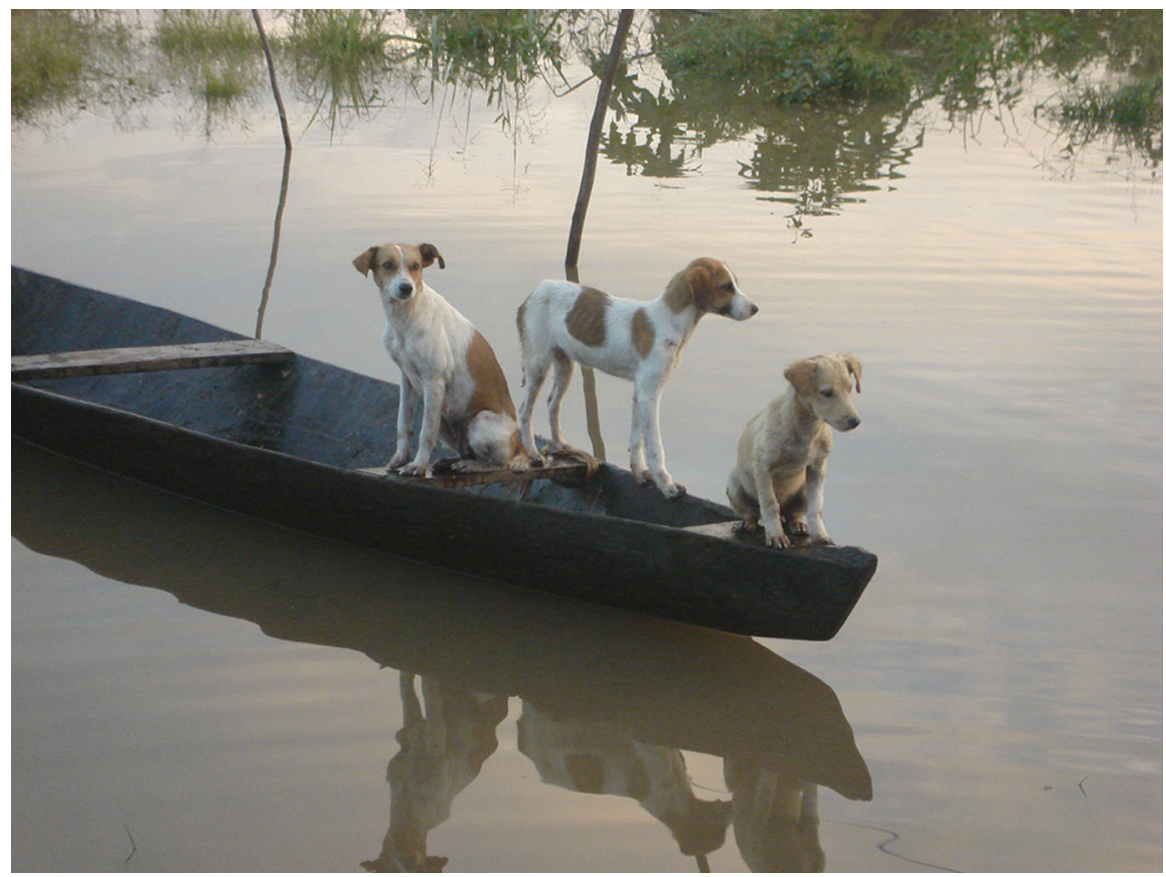

Fig. 10 Dogs were apparently unknown in Amazonia before European settlement, but in many cases were subsequently quickly taken up by Native people. These three dogs occupy a Kanamari canoe in the far west of Brazil's Amazon region. Courtesy of Luiz Costa

factors enter into the decision to keep dogs. However, while in historical times some groups, like the Sirionó and the Makuna (of southwestern and northwestern Amazonia respectively), took time to start using dogs when hunting, the fact is that they did do so, whereas the ethnographic, ethnohistorical, and archaeological records suggest that dogs were not used across most of lowland South America in pre-Columbian times. Something else must therefore have been at work.

Citing Johnson (2003), Koster (2009, p. 593) mentions 'environmental hazards' as another possible constraint on the presence of dogs in Amazonia, noting their 'high mortality' in Neotropical habitats (Koster 2009, p. 593). He further observes that on the margins of the forest, for example in the foothills of Peru's Cordillera Oriental, a lack of jaguars and other predators may have tipped the balance in favour of keeping dogs (Raimondi 1867, p. 131), and canine populations there may have had to be maintained by continual imports from nearby highlands (Schwartz 1997, p. 40). But what provoked this 'high mortality'? Koster (2009, p. 591) identifies several factors, including accidents; attacks by wild felids, peccaries, and snakes; malnutrition; and 'various diseases and mange.' Although there is a dearth of detailed information on canine birth and death rates, his own data from Nicaragua indicate an annual mortality rate there of $49 \%$ among adult dogs, with a further $50 \%$ of puppies dying as neonates (Koster 2008b). A high mortality rate 'primarily due to infectious diseases' is also described for rural Panama (Pineda et al. 2011, p. 362). 
Within South America, Yu (1997, p. 166) indicates that almost no puppies survive to adulthood on the Venezuelan savannahs, while Fiorello et al. (2006) report that $73 \%$ of puppies die as neonates and $34 \%$ of adults die each year in the Isoso area of southeastern Bolivia. None of these figures suggests that it is easy for dogs to sustain their populations in Neotropical habitats.

While Koster (2009) refrains from specifying the disease challenges that may contribute to these high mortality rates, I submit that the long-established presence in wild animal populations of diseases such as canine distemper, canine trypanosomiasis, visceral leishmaniasis, and-to the south of the Amazon Basin - canine rangeliosis helps to explain the limited distribution and the staggered expansion of dogs in South (and perhaps also Central) America. Specifically with regard to wild canids, recall also that neither bush dogs nor maned wolves appear to suffer from canine distemper, and that crab-eating foxes suffer no ill effects from canine rangeliosis (its impact on maned wolves and Pampas foxes is less certain; de Quadros et al. 2015; Silveira et al. 2016). With the exception of the Guianas (occupied by bush dogs) and the northern cost of Venezuela and Colombia (occupied by crab-eating foxes), the overlapping distributions of these three taxa (Fig. 5) correspond remarkably well to the majority of those areas of South America (Amazonia, the Gran Chaco, and the savannahs of southern and south-central Brazil) from which dogs appear to have been absent in pre-Columbian times. The obvious exception - the bulk of the Southern Cone-lies immediately to their south and dogs appear only to have entered its northern fringes late and from across the Andes. Conversely, the Pacific coast of southern Ecuador, Peru, and northern Chile and the northern and central Andes - areas in which dogs established themselves from about $3000 \mathrm{BC}$ onward-are all regions from which the three wild canids I have just named are absent and where, if my argument is correct, it may thus have been easier for dogs to expand.

Several lines of evidence need to be explored to evaluate further the ideas I have developed here. Direct dating of already known canine remains will provide a more accurate chronology for the dog's presence in South America and to its north, one that may, of course, be modified by future fieldwork. Direct evidence of the presence of known pathogens in ancient dog remains would help establish their antiquity and is not beyond the bounds of possibility given previous research on the palaeopathology of mummified dogs from Peru and Chile (Brothwell et al. 1979; Richardson et al. 2012). Analysis of canine dental calculus using ZooMS (Zooarchaeology by Mass Spectrometry; Buckley et al. 2009) to isolate and identify pathogen DNA (e.g. Weyrich et al. 2015) may also be possible as research in these fields develops; the latter can also be recovered from victims' bones in favourable circumstances (e.g. Costa Junqueira et al. 2009, with reference to human sufferers of mucocutaneous leishmaniasis). More detailed study of the phylogenetics of canine distemper to resolve the conflict between the results obtained by Panzera et al. (2015) and the historical record is certainly needed too, but phylogenetic analyses could be applied more extensively to other diseases as well. In the case of canine rangeliosis, for example, confirmation of an antiquity of $\geq 1800$ years would reinforce the case for it having spilt over from wild canids 
into domestic dogs, given that dogs are not known in Rio Grande do Sul, Uruguay, and central eastern Argentina before this.

Working together, geneticists and veterinarians might also investigate whether breeds of dog native to the Neotropics show signs of having evolved a degree of resistance to the diseases I have discussed, comparable to the partial immunity to canine babesiosis, canine monocytic ehrlichiosis, and Trypanosoma congolensederived canine trypanosomiasis that characterise some African dog populations relative to animals newly imported to Africa from Europe (Mitchell 2015). Today, most of the dogs found in Central and South America have a predominantly European ancestry. However, this is limited in recognised native breeds, such as the Mexican Chihuahua and the hairless perro sin pelo (viringo) of Peru (Fig. 11) and xoloitzcuintle of Mexico, all three of which share a unique mitochondrial haplotype suggestive of a shared ancestry (van Asch et al. 2013, p. 8). This is consistent with a derivation of the perro sin pelo via maritime contact with western Mexico (cf. Callaghan 2003), albeit probably only in the first millennium AD based on dates for faunal remains attributed to the breed in both Mesoamerica and Peru (Cordy-Collins 1994; Málaga and Ramírez 2015, p. 62; Valadez Azúa et al. 2009). Note, however, that representations of what appears to be this breed in Late Formative Chorrera pottery from coastal Ecuador may nevertheless imply a yet earlier (first millennium cal. BC) transfer, but in the opposite direction (Lathrap et al. 1975; Stahl 1984, p. 208).

Interestingly, the absence of one or more premolars in most dog mandibles of Saladoid date (c. $500 \mathrm{cal}$. BC-cal. AD 600) in the Antilles also indicates a

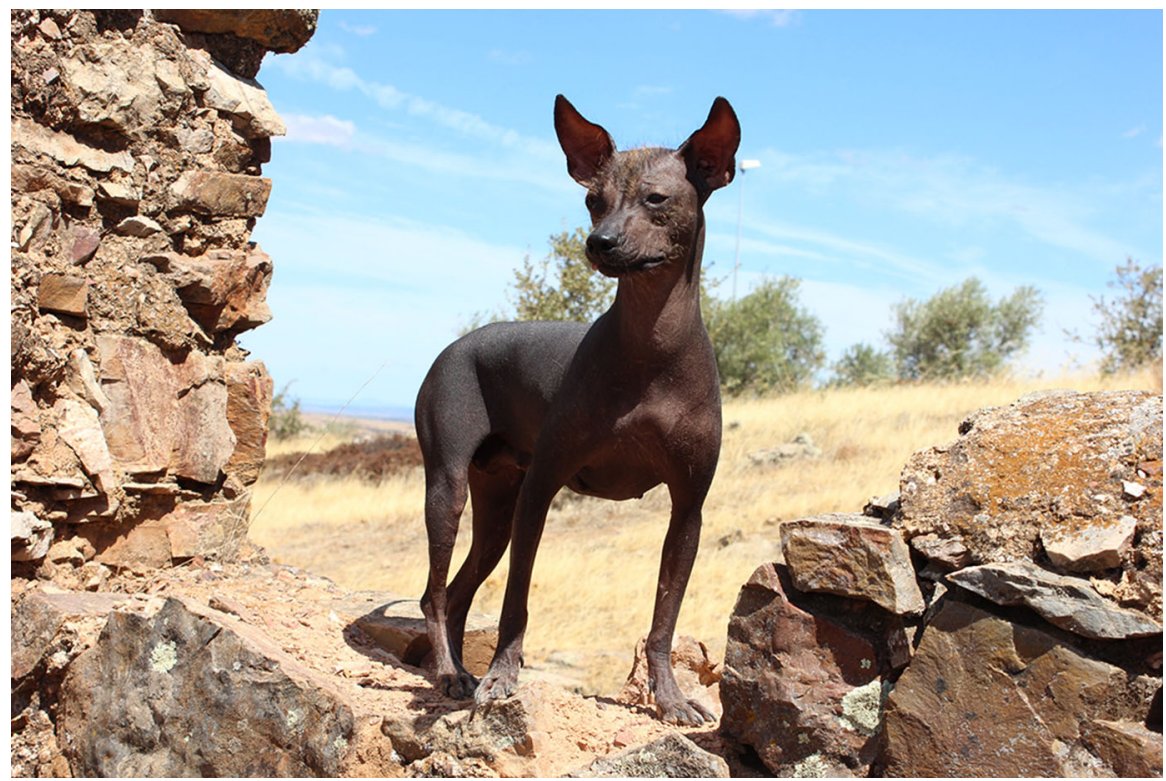

Fig. 11 The perro sin pelo of Peru. Photograph taken by Paradais Sphynx on 25 August 2012 and reproduced under a Creative Commons Attribution-Share Alike 3.0 Unported license from https:// commons.wikimedia.org/wiki/File:Perro-sin-pelo-del-peru.JPG 
connection to these hairless breeds because this condition is known to be associated with an allele linked to hairlessness in a phenotype known as canine ectodermal dysplasia (Grouard et al. 2013). Given that hairlessness is inherited as a monogenic autosomal semidominant trait caused by a mutation of the FOX13 gene, with heterozygous dogs being hairless but homozygous ones dying in embryo (Drögemuller et al. 2008), 'these dogs must have been viewed as valuable' (Schwartz 1997, p. 133) for the phenotype to survive. Might this condition, which is also shared by Argentine pila dogs and the khala of Bolivia's Andes, therefore survive not just by human selection, but because it provides a degree of immunity against disease? And does it have any bearing on the origin of pre-Columbian dogs in the West Indies (even though archaeological, linguistic, and archaeogenetic evidence strongly supports multiple northward movements of people from Southnot Central-America; Fitzpatrick 2015; Torres 2016)? As far as I can determine both possibilities remain to be investigated, though anecdotally 'high natural resistance to ailments ranging from distemper to fleas' has been noted in the xoloitzcuintle at least (Fernandez 2012, p. 38, emphasis added).

Finally, we should bear in mind that this paper does not exhaust the diseases to which dogs may have been exposed. The severity of canine monocytic ehrlichiosis caused by Ehrlichia canis, a post-Columbian import to the New World, is well known, but the effects of its New World relatives (E. chaffeensis and E. ewingii) merit further exploration; often impossible to differentiate from $E$. canis by conventional screening techniques, the former also produces severe disease in dogs with manifestations that are 'clinically, hematologically, and serologically indistinguishable' from those of E. canis (Breitschwerdt et al. 1998, p. 2649). The pathology of other tick-borne diseases also warrants investigation, including the extremely severe and potentially fatal infection caused by Rickettsia ricketsii (Rocky Mountain or Brazilian spotted fever), the vector for which (Amblyomma cajennense) occurs widely in Central and South America, with primary hosts including tapirs and capybaras (Hydrochoerus hydrochaeris) (Horta et al. 2004; Nicholson et al. 2010). And, as a third example, consider the almost invariably fatal bacterial-induced condition known as salmon poisoning disease, instances of which are now known from southeastern Brazil (Headley et al. 2011).

For these and for other canine vector-borne diseases several recent reviews indicate the scantiness of existing data in the Neotropics, even while acknowledging that they are common and widespread (e.g. Wei et al. 2014). Data on infections affecting native wildlife are also deficient (Headley et al. 2012, p. 1953). Furthermore, with all the pathogens I have mentioned, appreciation of their potential impact on the expansion of the dog into South America would benefit from more knowledge of their hosts, of the climatic and ecological tolerances of both hosts and vectors, and of how the distributions of both may have altered jointly in response to past climatic change and/or human modification of the landscape (cf. Diego et al. 2013). Better understanding of the circumstances in which some Amazonian groups have accepted dogs in recent times would also be informative. Do European-derived dogs possess greater resistance to disease than their native American predecessors? Does access to a degree of veterinary care improve their life chances in some favoured locations? Or did access to metal tools, firearms, and 
other ultimately European imports sufficiently alter the balance between losing dogs to disease and predators and the gains derived from hunting with them to make keeping them worthwhile?

'That the dog was introduced into South America much later during the Holocene' than its earlier presence further north might lead us to expect and that it 'may have been absent throughout the Amazon basin' into the very recent past (Stahl 2012, p. 108) seems well established. Whatever the roles of cultural ontology or optimisation of hunting returns, the high mortality dogs continue to experience across much of the Neotropics suggests that infectious disease should be taken seriously as one constraint on where and when they expanded in South America. On a global scale the arguments advanced here reinforce the case made previously by Larson et al. (2012) with reference to people and dogs, and by Diamond (1997, 2002) with respect to animal and plant domesticates as a whole, that movement is far simpler for human communities and their commensals along latitudes than it is across them. Future work should now investigate whether this holds true for dogs not just in South America and sub-Saharan Africa (Mitchell 2015), but also in other regions of the world.

Acknowledgements I should like to thank Ramiro Barberena, Monica Berón, Paulo Büll, Elizabeth Ewart, Erik Marsh, Patrick Roberts, Felipe Vander Velden, Tim Taylor, and an anonymous referee for their comments on an earlier draft of this paper; James Pugin and Sam Lunn-Rockliffe for preparing the maps that accompany it; and Monica Berón and Luiz Costa for kindly providing some of the other illustrations. While I cite the results of studies involving the deliberate infection of dogs in this paper, I do not approve of such experiments.

Open Access This article is distributed under the terms of the Creative Commons Attribution 4.0 International License (http://creativecommons.org/licenses/by/4.0/), which permits unrestricted use, distribution, and reproduction in any medium, provided you give appropriate credit to the original author(s) and the source, provide a link to the Creative Commons license, and indicate if changes were made.

\section{References}

Acosta, A. A., Buc, N., \& Davireux, M. N. (2015). Producción y uso de ornamentos en las tierras bajas de Sudamérica: El caso de las poblaciones humanas prehispánicas del extremo meridional de la cuenca del Plata (Argentina). Munibe Antropologia-Arkeologia, 66, 309-325.

Acosta, A. A., Loponte, D., \& Esponda, C. G. (2011). Primer registro de perro doméstico prehispánico (Canis familiaris) entre los grupos cazadores recolectores del humedal de Paraná inferior (Argentina). Antipoda: Revista de Antropología y. Arqueología, 13, 175-199.

Acosta-Jarnett, G., Chalmers, W. S., Cunningham, A. A., Cleaveland, S., Handel, I. G., \& Bronsvoort, B. M. (2011). Urban domestic dog populations as a source of canine distemper virus for wild carnivores in the Coquimbo region of Chile. Veterinary Microbiology, 152, 247-257.

Aguilar, H. M., Abad-French, F., Pinto Dias, J. C., Junqueira, A. C. V., \& Coura, J. R. (2007). Chagas disease in the Amazon region. Memórias do Instituto Oswaldo Cruz, 102(Supplement 1), 47-55.

Alexander, K. A., \& Appel, M. J. G. (1994). African wild dogs (Lycaon pictus) endangered by a canine distemper epizootic among domestic dogs near the Masai Mara National Reserve, Kenya. Journal of Wildlife Diseases, 30, 481-485.

Alexander, K. A., Kat, P. W., House, J., House, C., O’Brien, S. J., Laurenson, M. K., et al. (1995). African horse sickness and African carnivores. Veterinary Microbiology, 47, 133-140. 
Allison, M. J., Focacci, G., \& Santoro, C. (1982). The pre-Columbian dog from Arica, Chile. American Journal of Physical Anthropology, 59, 299-304.

Alva, W., \& Donnan, C. B. (1993). Royal tombs of Sipán. Los Angeles: Fowler Museum of Cultural History.

Andrade, A. S. R., \& Melo, M. N. (2015). Non-invasive molecular diagnosis of canine visceral leishmaniasis using conjunctival swab samples. In D. M. Claborn (Ed.), Leishmaniasis-Trends in epidemiology, diagnosis and treatment (pp. 195-216), InTech. doi:10.5772/57304. http://www. intechopen.com/books/leishmaniasis-trends-in-epidemiology-diagnosis-and-treatment/non-invasivemolecular-diagnosis-of-canine-visceral-leishmaniasis-using-conjunctival-swab-samples. Site accessed May 25, 2016.

Andrade, Z. A., Andrade, S. G., \& Sadigursky, M. (1984). Damage and healing in the conducting tissue of the heart (an experimental study in dogs infected with Trypanosoma cruzi). Journal of Pathology, $143,93-101$.

Angulo Váldes, C. (1981). La tradición Malambo: Un complejo temprano en el noroeste de Suramérica. Bogotá: Fundación de Investigaciones Arqueológicas Nacionales.

Appel, M. J. G., \& Summers, B. A. (1999). Canine distemper: Current status. In L. E. Carmichael (Ed.), Recent advances in canine infectious diseases. http://www.ivis.org/advances/Infect_Dis_ Carmichael/appel/ivis.pdf?origin=publication_detail. Site accessed May 25, 2016.

Ardila, G. (1983). Arqueología del rescate en la zona norte del Proyecto Carbonífero del Cerrejón: Sitio del Palmar. Bogotá: Carbacol, EPAM.

Aufderheide, A. C., Salo, W., Madden, M., Streitz, J., Buikstra, J., Guhl, F., et al. (2004). A 9,000-year record of Chagas' disease. Proceedings of the National Academy of Sciences of the United States of America, 101, 2034-2039.

Austin, J. J., Sourbier, J., Prevosti, F. J., Prates, L., Trejo, V., Mena, F., et al. (2013). The origins of the enigmatic Falklands Islands wolf. Nature Communications. doi:10.1038/ncomms2570.

Beineke, A., Baumgärtner, W., \& Wohlsein, P. (2015). Cross-species transmission of canine distemper virus-An update. One Health, 1, 49-59.

Bern, C., Kjos, S., Yabsley, M. J., \& Montgomery, S. P. (2011). Trypanosoma cruzi and Chagas' disease in the United States. Clinical Microbiology Reviews, 24, 655-681.

Berón, M., Prates, L., \& Prevosti, F. J. (2015). Una historia de perros: Mitos y certezas sobre su origen y dispersion en América. Ciencia Hoy, 25, 39-45.

Bird, J. (1946). The Alcaluf. In J. H. Steward (Ed.), Handbook of South American Indians, Volume 1: The marginal tribes (pp. 55-80). Washington: Smithsonian Institution.

Blancou, J. (2004). Dog distemper: Imported into Europe from South America? Historia Medicinae Veterinariae, 29, 35-41.

Blick, J. P., Bankston, A., Campbell, C., Jackson, J., Lasting, S., Mixon, E., \& Smith, L. (2016). Dogs of the Bahamas and Caribbean: Evidence from Columbus's Diario, historical documents, and archaeology. In R. Erdman \& R. Morrison (Eds.), Proceedings of the Fifteenth Symposium on the Natural History of the Bahamas (pp. 109-123). San Salvador: Gerace Research Centre.

Bonavia, D. (2008). The South American camelids. Los Angeles: Cotsen Institute of Archaeology.

Boudadi-Maligne, M., \& Escarguel, G. (2014). A biometric re-evaluation of recent claims for Early Upper Palaeolithic wolf domestication in Eurasia. Journal of Archaeological Science, 45, 80-89.

Boyce, J. (2006). Canine revolution: The social and environmental impact of the introduction of the dog to Tasmania. Environmental History, 11, 102-129.

Bracco, R., Cabrera, L., \& López Mazz, J. (2000). La prehistoria de las Tierras Bajas de la Cuenca de la laguna Merín. In A. Durán \& R. Bracco (Eds.), Arqueología de las Tierras Bajas (pp. 13-38). Montevideo: Imprenta Americana.

Breitschwerdt, E. B., Hegarty, B. C., \& Hancock, S. I. (1998). Sequential evaluation of dogs naturally infected with Ehrlichia canis, Ehrlichia chaffeensis, Ehrlichia equi, Ehrlichia ewingii, or Bartonella vinsonii. Journal of Clinical Microbiology, 36, 2645-2651.

Bresalier, M., \& Worboys, M. (2014). 'Saving the lives of our dogs': The development of canine distemper vaccine in interwar Britain. British Journal of the History of Science, 47, 305-334.

Brothwell, D., Malaga, A., \& Burleigh, R. (1979). Studies on Amerindian dogs, 2: Variation in early Peruvian dogs. Journal of Archaeological Science, 6, 139-161.

Buckley, M., Collins, M., Thomas-Oates, J., \& Wilson, J. C. (2009). Species identification by analysis of bone collagen using matrix-assisted laser desorption/ionisation time-of-flight mass spectrometry. Rapid Communications in Mass Spectrometry, 23, 3843-3854. 
Byrd, K. A. (1976). Changing animal utilization patterns and their implications: Southwest Ecuador, $6500 B C-A D$ 1400. PhD thesis, University of Florida.

Cabrera, A. (1934). El perro cimarrón de la Pampa argentina. Publicaciones del Museo Antropológico y Etnográfico de la Facultad de Filosofía y Letras, Serie A, 2, 7-29.

Callaghan, R. T. (2003). Prehistoric trade between Ecuador and western Mexico: A computer simulation of coastal voyages. Antiquity, 77, 796-804.

Cantacessi, C., Dantas-Torres, F., Nolan, M. J., \& Otranto, D. (2015). The past, present, and future of Leishmania genomics and transcriptomics. Trends in Parasitology, 31, 100-108.

Cardich, A., Tonni, E. P., \& Kriscautzky, N. (1977). Presencia de Canis familiaris en Los Toldos (Santa Cruz). Relaciones de la Sociedad Argentina de Antropología, 11, 115-119.

Caviglia, S. (1985/86). Nuevos restos de cánidos tempranos en sitios arqueológicos de Fuego-Patagonia. Anales del Instituto de la Patagonia, 16, 85-93.

Center for Food Security and Public Health (2009). Leishmaniasis (cutaneous and visceral). http://www. cfsph.iastate.edu/Factsheets/pdfs/leishmaniasis.pdf. Site accessed May 25, 2014.

Cooke, R., Jímenez, M., \& Ranere, A. (2007). Influencias humanas sobre la vegetación y fauna de vertebrados de Panamá: Actualización de datos arqueozoológicos y su relación con el paisaje antrópico durante la época precolombina. In E. G. Leigh, E. A. Herre, J. B. C. Jackson, \& F. SantosGranero (Eds.), Ecología y evolución en los Trópicos (pp. 562-593). Panama City: Smithsonian Tropical Research Institute.

Cooper, J. M. (1946a). The Araucanians. In J. H. Steward (Ed.), Handbook of South American Indians, Volume 2: The Andean civilizations (pp. 687-760). Washington: Smithsonian Institution.

Cooper, J. M. (1946b). The Chono. In J. H. Steward (Ed.), Handbook of South American Indians, Volume 1: The marginal tribes (pp. 47-54). Washington: Smithsonian Institution.

Cordy-Collins, A. (1994). An unshaggy dog story: A bizarre canine is living evidence of prehistoric contact between Mexico and Peru. Natural History, 103(2), 34-41.

Costa Junqueira, M. A., Matheson, C., Iachetta, L., Llagostera, A., \& Appenzeller, O. (2009). Ancient leishmaniasis in a highland desert of northern Chile. PLOS ONE, 4(9), e6983.

Courtenay, O., Quinnell, R. J., \& Chalmers, W. S. (2001). Contact rates between wild and domestic canids: No evidence of parvovirus or canine distemper virus in crab-eating foxes. Veterinary Microbiology, 81, 9-19.

Crosby, A. W. (1986). The Columbian exchange: Biological and cultural consequences of 1492. Westport: Greenwood.

Cupul-Magaña, F. G., Mountjoy, J. B., \& Rhodes, J. A. (2014). Dientes de cánido (Canidae) asociados a un entierro del periodo Formativo medio en el valle de Mascota, Jalisco. Arqueología, 48, 69-76.

Curi, N. H. A., Araújo, A. S., Campos, F. S., Lobato, Z. I. P., Gennari, S. M., Marvulo, M. F. V., et al. (2010). Wild canids, domestic dogs and their pathogens in southeast Brazil: Disease threats for canid conservation. Biodiversity and Conservation, 19, 3513-3524.

Curi, N. H. A., Coelho, C. M., de Campos Cordeiro Malta, M., Magni, E. M., Sábato, M. A., Araújo, A. S., et al. (2012). Pathogens of wild maned wolves (Chrysocyon brachyurus) in Brazil. Journal of Wildlife Diseases, 48, 1052-1056.

Dantas-Torres, F. (2009). Canine leishmaniasis in South America. Parasites \& Vectors, 2(Supplement 1), S1.

Dantas-Torres, F., \& Otranto, D. (2014). Dogs, cats, parasites, and humans in Brazil: Opening the black box. Parasites \& Vectors, 7, 22.

Dantas-Torres, F., Solano-Gallego, L., Baneth, G., Ribeiro, V. M., de Paiva-Cavalcanti, M., \& Otranto, D. (2012). Canine leishmaniosis in the Old and New Worlds: Unveiled similarities and differences. Trends in Parasitology, 28, 531-538.

De Lana, M., Chiara, E., \& Tafuri, W. L. (1992). Experimental Chagas' disease in dogs. Memórias do Instituto Oswaldo Cruz, 87, 57-91.

de Quadros, R. M., Soares, J. F., Xavier, J. S., Pilati, C., da Costa, J. L., Miotto, B. A., et al. (2015). Natural infection of the wild canid Lycalopex gymnocercus by the protozoan Rangelia vitalii, the agent of canine rangeliosis. Journal of Wildlife Diseases, 51, 787-789.

De Souza-Mazurek, R. R., Pedrinho, T., Feliciano, X., Hilário, W., Gerôncio, S., \& Marcelo, E. (2000). Subsistence hunting among the Waimiri Atroari Indians in central Amazonia, Brazil. Biodiversity and Conservation, 9, 579-596.

De Viedma, A. (1837). Diario de un viaje a la costa de Patagonia. Buenos Aires: Imprenta del Estado. 
Deem, S. L., \& Emmons, L. H. (2000). Exposure of free-ranging maned wolves (Chrysocyon brachyurus) to infectious and parasitic disease agents in the Noël Kempff Mercado National Park, Bolivia. Journal of Zoo and Wildlife Medicine, 36, 192-197.

Deem, S. L., Spelman, L. H., Yates, R. A., \& Montali, R. J. (2000). Canine distemper in terrestrial carnivores: A review. Journal of Zoo and Wildlife Medicine, 31, 441-451.

Descola, P. (2001). The genres of gender: Local models and paradigms in the comparison of Amazonia and Melanesia. In T. H. Gregor \& D. Tuzin (Eds.), Gender in Amazonia and Melanesia. An exploration of the comparative method (pp. 91-114). Berkeley: University of California Press.

Diamond, J. (1997). Guns, germs, and steel: The fates of human societies. New York: W. W. Norton.

Diamond, J. (2002). Evolution, consequences and future of plant and animal domestication. Nature, 418, 700-707.

Diego, J. G. R., Olivares, J. L., Sánchez Castilleja, Y., Alemán, Y., \& Arece, J. (2013). Cambios climáticos y su efecto sobre algunos grupos de parásitos. Revista de Salud Animal, 35, 145-150.

Dikov, N. N. (1996). The Ushki sites, Kamchatka Peninsula. In F. H. West (Ed.), American beginnings (pp. 244-250). Chicago: University of Chicago Press.

Dillehay, T. D. (2000). The settlement of the Americas. New York: Basic Books.

Dillehay, T. D., Ocampo, C., Saavedra, J., Sawakuchi, A. O., Vega, R. M., Pino, M., et al. (2015). New archaeological evidence for an early human presence at Monte Verde. Chile. PLoS ONE, 10(11), e0141923.

Ding, Z. L., Oskarsson, M., Ardalan, A., Angleby, J., Dahlgren, L. G., Tepeli, C., et al. (2012). Origins of domestic dog in southern East Asia is supported by analysis of Y-chromosome DNA. Heredity, 108, 507-514.

Dransart, P. Z. (2003). Earth, water, fleece and fabric: An ethnography and archaeology of Andean camelid herding. London: Routledge.

Drögemuller, C., Karlsson, E. K., Hytönen, M. K., Perloski, M., Dolf, G., Sainio, K., et al. (2008). A mutation in hairless dogs implicates FOXI3 in ectodermal development. Science, 321, 1462.

Druzhkova, A. S., Thalmann, O., Trifonov, V. A., Leonard, J. A., Vorobieva, N. V., Ovodov, N. D., et al. (2013). Ancient DNA analysis affirms the canid from Altai as a primitive dog. PLoS ONE, 8(3), e57754.

Duz, A. L. C., de Abreu Vieira, P. M., Roatt, B. M., Aguiar-Soares, R. D. O., de Oliveira Cardoso, J. M., de Oliveira, F. C. B., et al. (2014). The TcI and TcII Trypanosoma cruzi experimental infections induce distinct immune responses and cardiac fibrosis in dogs. Memórias do Instituto Oswaldo Cruz, 109, 1005-1013.

Eiras, D. F., Basabe, J., Mesplet, M., \& Schnittger, L. (2008). First molecular characterization of Babesia vogeli in two naturally infected dogs of Buenos Aires, Argentina. Veterinary Parasitology, 157, 294-298.

Eiras, D. F., Craviotto, M. B., Baneth, G., \& Moré, G. (2014). First report of Rangelia vitalii infection (canine rangeliosis) in Argentina. Parasitology International, 63, 729-734.

Eloy, L. J., \& Lucheis, S. B. (2009). Canine trypanosomiasis: Etiology of infection and implications for public health. Journal of Venomous Animal Toxins including Tropical Diseases, 15, 589-611.

Enciso, A. J. A., Moreira, J. S., \& Marzochi, M. C. A. (2001). Lesión litica craniana por Leishmaniasis en Makat-tampu durante el imperio inca: Siglos XV-XVI, valle del bajo Rímac, Peru. Revista do Museu de Arqueologia e Etnologia, 11, 227-242.

Erickson, C. L. (2006). The domesticated landscape of the Bolivian Amazon. In W. Balée (Ed.), Time and complexity in historical ecology (pp. 235-278). New York: Columbia University Press.

Espinosa, O. A., Serrano, M. G., Camargo, E. P., Teixeira, M. M. G., \& Shaw, J. J. (2016). An appraisal of the taxonomy and nomenclature of trypanosomatids presently classified as Leishmania and Endrotrypanum. Parasitology, 15, 1-13.

Farabee, W. C. (1918). The central Arawaks. Philadelphia: University Museum.

Fernandez, A. (2012). Xoloitzcuintli (comprehensive owner's guide). Freebold: Kennel Club Books.

Fernández, P. M., \& Carballido Calatayud, M. (2015). Armas y presas: Técnicas de caza en el interior del bosque patagónico. Relaciones de la Sociedad Argentina de Antropología, 40, 279-301.

Ferreira, L. F., Jansen, A. M., \& Araújo, A. (2011). Chagas disease in prehistory. Anais da Academia Brasileira de Ciências, 83, 1041-1044.

Ferreyra, H., Calderón, M. G., Marticorena, D., Marull, C., \& Leonardo, B. C. (2009). Canine distemper infection in crab-eating fox (Cerdocyon thous) from Argentina. Journal of Wildlife Diseases, 45, $1158-1162$ 
Fiedel, S. J. (2005). Man's best friend-Mammoth's worst enemy? A speculative essay on the role of dogs in Paleoindian colonization and megafaunal extinction. World Archaeology, 37, 11-25.

Fighera, R. A., Souza, T. M., Silva, M. C., Brum, J. S., Graça, D. L., Kommers, G. D., et al. (2008). Causas de morte e razões para euthanasia de cães da Mesorregião do Centro Ocidental RioGrandense (1965-2004). Pesquisa Veterinária Brasileira, 28, 223-230.

Fiorello, C. V., Noss, A. J., \& Deem, S. L. (2006). Demography, hunting ecology, and pathogen exposure of domestic dogs in the Isoso of Bolivia. Conservation Biology, 20, 762-771.

Fitzpatrick, S. M. (2015). The pre-Columbian Caribbean: Colonization, population dispersal, and island adaptations. PaleoAmerica, 1, 305-331.

Flannery, K. V. (1967). Vertebrate fauna and hunting patterns. In D. S. Byers (Ed.), The prehistory of the Tehuacan Valley (pp. 132-177). Austin: University of Texas Press.

Fock, N. (1963). Waiwai: Religion and society of an Amazonian tribe. Copenhagen: National Museum.

Franca, R. T., Silva, A. S., Loretti, A. P., Mazzanti, C. M., \& Lopes, S. T. A. (2014). Canine rangeliosis due to Rangelia vitalii: From first report in Brazil in 1910 to current day-A review. Ticks and TickBorne Diseases, 5, 466-474.

Franca, R. T., Silva, A. S., Paim, F. C., Costa, M. M., Soares, J. F., Mazzanti, C. M., et al. (2010). Rangelia vitalii in dogs in southern Brazil. Comparative Clinical Pathology, 19, 383-387.

Frantz, L. A. F., Mullin, V. E., Pionnier-Capitan, M., Lebrasseur, O., Ollivier, M., Perri, A., et al. (2016). Genomic and archaeological evidence suggests a dual origin of domestic dogs. Science, 352, $1228-1230$.

Freedman, A. H., Gronau, I., Schweitzer, R. M., Ortega-Del Vecchyo, D., Han, E., Silva, P. M., et al. (2014). Genome sequencing highlights the dynamic early history of dogs. PLoS Genetics, 10(1), e1004016.

Freedman, A. H., \& Wayne, R. K. (2017). Deciphering the origin of dogs: From fossils to genomes. Annual Review of Animal Biosciences, 5, 281-307.

Frías, L., Leles, D., \& Araújo, A. (2013). Studies on protozoa in ancient remains-A review. Memórias do Instituto Oswaldo Cruz, 108, 1-12.

Fuller, D. Q., \& Hildebrand, E. (2013). Domesticating plants in Africa. In P. J. Mitchell \& P. J. Lane (Eds.), The Oxford handbook of African archaeology (pp. 507-526). Oxford: Oxford University Press.

Germonpré, M., Lázničková-Galetová, M., \& Sablin, M. V. (2012). Palaeolithic dog skulls at the Gravettian Předmostí site, the Czech Republic. Journal of Archaeological Science, 39, 184-202.

Germonpré, M., Sablin, M. V., Lázničková-Galetová, M., Després, V., Stevens, R. H., Stiller, M., et al. (2015). Palaeolithic dogs and Pleistocene wolves revisited: A reply to Morey (2014). Journal of Archaeological Science, 54, 210-216.

Germonpré, M., Sablin, M. V., Stevens, R., Hedges, R. E. M., Hoftreiter, M., Stiller, M., et al. (2009). Fossil dogs and wolves from Palaeolithic sites in Belgium, the Ukraine and Russia: Osteometry, ancient DNA and stable isotopes. Journal of Archaeological Science, 36, 473-490.

Giannitti, F., Diab, S. S., Uzal, F. A., Fresneda, K., Rossi, D., Talmi-Frank, D., et al. (2012). Infection with a Hepatozoon sp. closely related to Hepatozoon felis in a wild Pampas gray fox (LycalopexPseudalopex-gymnocercus) co-infected with canine distemper virus. Veterinary Parasitology, 186, 497-502.

Gifford-Gonzalez, D. P. (2000). Animal disease challenges to the emergence of pastoralism in subSaharan Africa. African Archaeological Review, 17, 95-139.

Gifford-Gonzalez, D. P. (2017). 'Animal disease challenges' fifteen years later: The hypothesis in light of new data. Quaternary International, 436, 283-293.

Gillin, J. (1948). Tribes of the Guianas. In J. H. Steward (Ed.), Handbook of South American Indians, Volume 3: The tropical forest tribes (pp. 799-860). Washington: Smithsonian Institution.

Giovas, C. M., LeFebvre, M. J., \& Fitzpatrick, S. M. (2012). New records for prehistoric introduction of Neotropical mammals to the West Indies: Evidence from Carriacou, Lesser Antilles. Journal of Biogeography, 39, 476-487.

Greene, G. E., \& Appel, M. J. (1990). Canine distemper. In C. E. Green (Ed.), Infectious diseases of the dog and cat (pp. 226-241). Philadelphia: W.B. Saunders.

Grotti, V. (2013). The wealth of the body: Trade relations, objects, and personhood in northeastern Amazonia. Journal of Latin American and Caribbean Anthropology, 18, 14-30.

Grouard, S., Perdikaris, S., \& Debue, K. (2013). Dog burials associated with human burials in the West Indies during early pre-Columbian Ceramic Age (500 BC-600 AD). Anthropozoologica, 48, $447-465$. 
Guhl, F., \& Ramírez, J. D. (2011). Trypanosoma cruzi I diversity: Towards the need of genetic subdivision? Acta Tropica, 119, 1-4.

Haas, J., Creamer, W., Mesía, L. H., Goldstein, D., Reinhard, K., \& Rodríguez, C. V. (2013). Evidence for maize (Zea mays) in the Late Archaic (3000-1800 B.C.) in the Norte Chico region of Peru. Proceedings of the National Academy of Sciences of the United States of America, 110, 4945-4949.

Hart, J. P., \& Lovis, W. A. (2013). Reevaluating what we know about the histories of maize in northeastern North America: A review of current evidence. Journal of Archaeological Research, 21, 175-216.

Headley, S. A., Amude, A. M., Alfieri, A. F., Bracarense, A. P. F., \& Alfieri, A. A. (2012). Epidemiological features and the neuropathological manifestations of canine distemper virusinduced infections in Brazil: A review. Semina: Ciências Agrárias, 33, 1945-1978.

Headley, S. A., Scorpio, D. G., Vidotto, O., \& Dumler, J. S. (2011). Neorickettsia helminthoeca and salmon poisoning disease: A review. The Veterinary Journal, 187, 165-173.

Hendricks, S. A., Sesink Clee, P. R., Harrigan, R. J., Pollinger, J. P., Freedman, A. H., Callas, R., et al. (2016). Re-defining historical geographic range in species with sparse records: Implications for the Mexican wolf reintroduction program. Biological Conservation, 194, 48-57.

Herrera, H. M., Rocha, F. L., Lisboa, C. V., Rademaker, V., Mourao, G. M., \& Jansen, A. M. (2011). Food web connections and the transmission cycles of Trypanosoma cruzi and Trypanosoma evansi (Kinetoplastida, Trypanosomatidae) in the Pantanal region, Brazil. Transactions of the Royal Society of Tropical Medicine and Hygiene, 105, 380-387.

Hidalgo-Mihart, M. G., Cantú-Salazar, L., González-Romero, A., \& Lópes-González, C. A. (2004). Historical and present distribution of coyote (Canis latrans) in Mexico and Central America. Journal of Biogeography, 31, 2025-2038.

Hogg, A. G., Hua, Q., Blackwell, P. G., Niu, M., Buck, C. E., Guilderson, T. P., et al. (2013). SHCal13 Southern Hemisphere calibration, 0-50,000 cal yr BP. Radiocarbon, 55, 1889-1903.

Horta, M. C., Labruna, M. B., Sangioni, L. A., Vianna, M. C. B., Gennari, S. M., Galvão, M. A. M., et al. (2004). Prevalence of antibodies to spotted fever group Rickettsiae in humans and domestic animals in a Brazilian spotted fever-endemic area in the state of São Paulo, Brazil: Serologic evidence for infection by Rickettsia ricketsii and another spotted fever group Rickettsia. American Journal of Tropical Medicine and Hygiene, 71, 93-97.

Hotez, P. J., Dumonteil, E., Cravioto, M. B., Bottazzi, M. E., Tapia-Conyer, R., Meymandi, S., et al. (2013). An unfolding tragedy of Chagas disease in North America. PLoS Neglected Tropical Diseases, 7(10), e2300.

Huffman, T. N. (1996). Archaeological evidence for climatic change during the last 2000 years in southern Africa. Quaternary International, 33, 55-60.

Jenkins, D. L., Davis, L. G., Stafford, T. W., Campos, P. F., Hockett, B., Jones, G. T., et al. (2012). Clovis age western stemmed projectile points and human coprolites at the Paisley Caves. Science, 337, 223-228.

Jesse, G. (1886). Researches into the history of the British dog. London: Hardwicke.

Johnson, A. (2003). Families of the forest: The Matsigenka Indians of the Peruvian Amazon. Berkeley: University of California Press.

King, P. P. (1839). Narrative of the surveying voyage of HMS Adventure and Beagle between the years 1826 and 1836, describing their examination of the southern shores of South America, and the Beagle's circumnavigation of the globe. London: Henry Colburn.

Kirchhoff, P. (1948). Food-gathering tribes of the Venezuelan Llanos. In J. H. Steward (Ed.), Handbook of South American Indians, Volume 4: The circum-Caribbean tribes (pp. 445-468). Washington: Smithsonian Institution.

Kjos, S. A., Snowden, K. F., Craig, T. M., Lewis, B., Ronald, N., \& Olson, J. K. (2008). Distribution and characterization of canine Chagas disease in Texas. Veterinary Parasitology, 152, $249-256$.

Koster, J. (2008a). The impact of hunting with dogs on wildlife harvests in the Bosawas Reserve, Nicaragua. Environmental Conservation, 35, 211-220.

Koster, J. (2008b). Hunting with dogs in Nicaragua: An optimal foraging approach. Current Anthropology, 49, 935-944.

Koster, J. (2009). Hunting dogs in the lowland Neotropics. Journal of Anthropological Research, 65, 575-610.

Labruna, M. B., McBride, J. W., Camargo, L. M. A., Aguiar, D. M., Yabsley, M. J., Davidson, W. R., et al. (2007). A preliminary investigation of Ehrlichia species in ticks, humans, dogs, and capybaras from Brazil. Veterinary Parasitology, 143, 189-195. 
Laffoon, J. E., Plomp, E., Davies, G. R., Hoogland, M. L. P., \& Hofman, C. L. (2015). The movement and exchange of dogs in the prehistoric Caribbean: An isotopic investigation. International Journal of Osteoarchaeology, 25, 454-465.

Lainson, R. (2012). The Neotropical Leishmania species: A brief historical review of their discovery, ecology and taxonomy. Revista Pan-Amazônica de Saúde, 1(2), 13-32.

Larson, G., \& Bradley, D. G. (2014). How much is that in dog years? The advent of canine population genomics. PLoS Genetics, 10(1), e1004093.

Larson, G., Karlsson, E. K., Perri, A., Webster, M. T., Ho, S. Y. W., Peters, J., et al. (2012). Rethinking dog domestication by integrating genetics, archeology, and biogeography. Proceedings of the National Academy of Sciences of the United States of America, 109, 8878-8883.

Lathrap, D. W., Collier, D., \& Chandra, H. (1975). Ancient Ecuador: Culture, clay and creativity 3000-300 BC. Chicago: Field Museum of Natural History.

Leblois, R., Kuhls, K., François, O., Schönian, G., \& Wirth, T. (2011). Guns, germs and dogs: On the origin of Leishmania chagasi. Infection, Genetics and Evolution, 11, 1091-1095.

Leonard, J. A., Wayne, R. K., Wheeler, J., Valadez Azúa, R., Guillén, S., \& Vilà, C. (2002). Ancient DNA evidence for Old World origin of New World dogs. Science, 298, 1613-1616.

Lima, V. S., Iniguez, A. M., Otsuki, K., Ferreira, L. F., Araújo, A., Vicente, A. C. P., et al. (2008). Chagas disease in ancient hunter-gatherer population, Brazil. Emerging Infectious Diseases, 14, 1000-1001.

López, Belotti, \& de Medina, C. R. (2012). En compañia de los Muertos. Ofrendas de animales en los cementerios de La Isla (Tilcara, Jujuy). Intersecciones en Antropología, 13, 345-357.

López, Belotti, \& de Medina, C. R. (2016). Morphometry of a pre-Hispanic dog from northwestern Argentina (AD 800-1200). International Journal of Osteoarchaeology. doi:10.1002/oa.2577.

López Mazz, J. M., \& Castiñera, C. (2001). Estructura de sitio y patron de asentamiento en la Laguna Negra (depot. de Rocha). In Arqueología Uruguaya hacia el fin del milenio: IX Congreso Nacional de Arqueología (pp. 147-174). Montevideo: Asociación Uruguaya de Arqueología.

Loponte, D., \& Acosta, A. (2016). Nuevos registros prehispánicos de Canis familiaris (Carnivora, Canidae) en la Cuenca del Paraná, Argentina. Mastozoología Neotropical, 23, 431-454.

Loponte, D., Acosta, A., \& Musali, J. (2005). Complexity among hunter-gatherers from the Pampean region, South America. In C. Grier, J. Kim, \& J. Uchiyama (Eds.), Beyond affluent foragers (pp. 106-125). Oxford: Oxbow Books.

Loretti, A. P., \& Barros, S. S. (2005). Hemorrhagic disease in dogs infected with an unclassified intraendothelial piroplasm in southern Brazil. Veterinary Parasitology, 21, 137-142.

Losey, R. J., Garvie-Lok, S., Leonard, J. A., Katzenberg, M. A., Germonpré, M., Nomokonova, T., et al. (2013). Burying dogs in ancient cis-Baikal, Siberia: Temporal trends and relationships with human diet and subsistence practices. PLoS ONE, 8(5), e63740.

Lupo, K. D., \& Janetski, J. C. (1994). Evidence of domesticated dogs and some related canids in the eastern Great Basin. Journal of California and Great Basin Anthropology, 16, 199-220.

Luppi, M. M., Malta, M. C. C., Silva, T. M. A., Silva, F. L., Motta, R. O. C., Miranda, I., et al. (2008). Visceral leishmaniasis in captive wild canids in Brazil. Veterinary Parasitology, 155, 146-151.

Macedo, A. M., \& Pena, S. D. J. (1998). Genetic variability of Trypanosoma cruzi: Implications for the pathogenesis of Chagas disease. Parasitology Today, 14, 119-124.

MacNeish, R. S., \& Vierra, R. K. (1983). The preceramic way of life in the Thorn Forest Riverine Ecozone. In R. S. MacNeish, R. K. Vierra, A. Nelken-Turner, R. Lurie, \& A. G. Cook (Eds.), Prehistory of the Ayacucho Basin, Peru, Volume 4: The preceramic way of life (pp. 48-129). Ann Arbor: University of Michigan Press.

Málaga, J. O., \& Ramírez, C. G. (2015). El viringo, el perro sin pelo del Perú: Patrimonio nacional peruano. Revista de Arquitectura, 2, 57-82.

Markgraf, V. (1993). Paleoenvironments and paleoclimates in Tierra del Fuego and southernmost Patagonia, South America. Palaeogeography, Palaeoclimatology, Palaeoecology, 102, 53-68.

Marsteller, S. J., Torres-Rouff, C., \& Knudson, K. J. (2011). Pre-Columbian Andean sickness ideology and the social experience of leishmaniasis: A contextualised analysis of bioarchaeological and paleopathological data from San Pedro de Atacama, Chile. International Journal of Paleopathology, $1,24-34$.

Matete, G. O. (2003). Occurrence, clinical manifestation and the epidemiological implications of naturally occurring canine trypanosomiasis in western Kenya. Onderstepoort Journal of Veterinary Research, 70, 317-323. 
Maywald, P. G., Machado, M. I., Costa-Cruz, J. M., \& Gonçalves-Pires, M. R. F. (1996). Leishmaniose tegumentar, visceral e doença de Chagas caninas em municípios do Triângulo Mineiro e Alto Paranaiba, Minas Gerais, Brasil. Cadernos Saúde Pública, 12, 321-328.

McInnes, E. F., Burroughs, R. E., \& Duncan, N. M. (1992). Possible vaccine-induced canine distemper in a South American bush dog (Speothos venaticus). Journal of Wildlife Diseases, 28, 614-617.

Megid, J., Souza, V. A., Teixeira, C. R., Cortez, A., Amorin, R., Heinemann, M. B., et al. (2009). Canine distemper virus in a crab-eating fox (Cerdocyon thous) in Brazil: Case report and phylogenetic analyses. Journal of Wildlife Diseases, 45, 527-530.

Megid, J., Teixeira, C. R., Amorin, R. L., Cortez, A., Heinemann, M. B., de Paula Antunes, J. M., et al. (2010). First identification of canine distemper virus in hoary fox (Lycalopex vetulus): Pathologic aspects and virus phylogeny. Journal of Wildlife Diseases, 46, 303-305.

Mena, F. L., Omar Reyes, B., Stafford, T. W., \& Southon, J. (2003). Early human remains from Baño Nuevo-1 Cave, central Patagonian Andes, Chile. Quaternary International, 109(110), 113-121.

Mendoza España, V., \& Valadez Azúa, R. (2006). El perro prehispánico andino: Función y tipos a partir del análisis arquezoológico. In Anales del XIX Reunión Anual del Etnología (pp. 31-38). La Paz: Museo Nacional de Etnografía y Folklore.

Métraux, A. (1946). Indians of the Gran Chaco. In J. H. Steward (Ed.), Handbook of South American Indians, Volume 1: The marginal tribes (pp. 197-370). Washington: Smithsonian Institution.

Métraux, A. (1948). The hunting and gathering tribes of the Rio Negro Basin. In J. H. Steward (Ed.), Handbook of South American Indians, Volume 3: The tropical forest tribes (pp. 861-882). Washington: Smithsonian Institution.

Milheira, R. G., Loponte, D. M., Esponda, C. G., Acosta, A., \& Ulgium, P. (2017). The first record of a pre-Columbian domestic dog (Canis lupus familiaris) in Brazil. International Journal of Osteoarchaeology, 27, 488-494.

Millais, E. (1890). The pathogenic microbe of distemper in dogs, and its use for protective inoculation. British Medical Journal, 1(1528), 856-860.

Miller, G. R., \& Gill, A. L. (1990). Zooarchaeology at Pirincay, a Formative Period site in highland Ecuador. Journal of Field Archaeology, 17, 49-68.

Mitchell, P. J. (2002). The archaeology of southern Africa. Cambridge: Cambridge University Press.

Mitchell, P. J. (2015). Did disease constrain the spread of domestic dogs (Canis familiaris) into subSaharan Africa? Azania: Archaeological Research in Africa, 50, 92-135.

Mitchell, P. J. (2017). The constraining role of disease on the spread of domestic mammals in subSaharan Africa: A review. Quaternary International. doi:10.1016/j.quaint.2017.05.011.

Monaghan, G. W., Schilling, T. M., \& Parker, K. E. (2014). The age and distribution of domesticated beans (Phaseolus vulgaris) in eastern North America: Implications for agricultural practices and group interactions. Midwest Archaeological Conference Inc. Occasional Papers, 1, 161-174.

Morey, D. F. (2006). Burying key evidence: The social bond between dogs and people. Journal of Archaeological Science, 33, 158-175.

Morey, D. F. (2014). In search of Paleolithic dogs: A quest with mixed results. Journal of Archaeological Science, 52, 200-307.

Morey, D. F., \& Wiant, M. D. (1992). Early Holocene domestic dog burials from the North American Midwest. Current Anthropology, 33, 224-229.

Morey, F. F., \& Jeger, R. (2017). From wolf to dog: Late Pleistocene ecological dynamics, altered trophic strategies, and shifting human perceptions. Historical Biology, 29, 895-903.

Morrison, W. I., Murray, M., Sayer, P. D., \& Preston, J. M. (1980). The pathogenesis of experimentally induced Trypanosoma brucei infection in the dog: 1. tissue and organ damage. American Journal of Pathology, 102, 168-181.

Nambulli, S., Sharp, C. R., Acciardo, A. S., Drexler, J. F., \& Duprex, W. P. (2016). Mapping the evolutionary trajectories of morbilliviruses: What, where and whither. Current Opinion in Virology, 16, 95-105.

Nicholson, W. L., Allen, K. E., McQuiston, J. H., Breitschwerdt, E. B., \& Little, S. E. (2010). The increasing recognition of rickettsial pathogens in dogs and people. Trends in Parasitology, 26, 205-212.

Nimuendaju, C. (1948). The Maué and Arapium. In J. H. Steward (Ed.), Handbook of South American Indians, Volume 3: The tropical forest tribes (pp. 245-254). Washington: Smithsonian Institution.

Niskanen, A. K., Hagström, E., Lohi, H., Ruokonen, M., Esparza-Salas, R., Aspi, J., et al. (2013). MHC variability supports dog domestication from a large number of wolves: High diversity in Asia. Heredity, 110, 80-85. 
Nobrega, A. A., Garcia, M. H., Tatto, E., Obara, M. T., Costa, E., Sobel, J., et al. (2009). Oral transmission of Chagas disease by consumption of açaí palm fruit, Brazil. Emerging Infectious Diseases, 15, 653-655.

Pache, M., Wichmann, S., \& Zhivlov, M. (2016). Words for 'dog' as a diagnostic of language contact in the Americas. In A. L. Berez-Kroeker, D. M. Hintz, \& C. Jany (Eds.), Language contact and change in the Americas: Studies in honour of Marianne Mithun (pp. 385-410). Amsterdam: John Benjamins Publishing Company.

Pang, J. F., Kluetsch, C., Zou, X. J., Zhang, A. B., Luo, L. Y., Angleby, H., et al. (2009). mtDNA data indicate a single origin for dogs south of Yangtze River, less than 16,300 years ago, from numerous wolves. Molecular Biology and Evolution, 26, 2849-2864.

Panzera, Y., Sarute, N., Carrau, L., Aldaz, J., \& Pérez, R. (2014). Genetic diversity of canine distemper virus in South America. British Journal of Virology, 1(2), 48-53.

Panzera, Y., Sarute, N., Iraola, G., Hernández, M., \& Pérez, R. (2015). Molecular phylogeography of canine distemper virus: Geographic origin and global spreading. Molecular Phylogenetics and Evolution, 92, 147-154.

Penzhorn, B. (2011). Why is southern African canine babesiosis so virulent? An evolutionary perspective. Parasites \& Vectors, 4, 51.

Peres, C. A. (1996). Population status of white-lipped Tayasu pecari and collaried peccaries T. tajacu in hunted and unhunted Amazonian forests. Biological Conservation, 77, 115-123.

Peres, C. A. (2000). Evaluating the impact and sustainability of subsistence hunting at multiple Amazonian forest sites. In J. G. Robinson \& E. L. Bennett (Eds.), Hunting for sustainability in tropical forests (pp. 31-56). New York: Columbia University Press.

Perini, F. A., Russo, C. A. M., \& Schrago, C. G. (2010). The evolution of South American endemic canids: A history of rapid diversification and morphological parallelism. Journal of Evolutionary Biology, 23, 311-322.

Perri, A. R., Smith, G. M., \& Bosch, M. D. (2015). Comment on 'How do you kill 86 mammoths? Taphonomic investigations of mammoth megasites' by Pat Shipman. Quaternary International, 368, 112-115.

Pestle, W. J. (2010). Diet and society in prehistoric Puerto Rico: An isotopic approach. PhD thesis, University of Illinois at Chicago.

Phillipson, D. W. (1979). The later prehistory of eastern and southern Africa. London: Heinemann.

Pineda, V., Saldaña, A., Monfante, I., Santamaría, A., Gottdenker, N. L., Yabsley, M. J., et al. (2011). Prevalence of trypanosome infections in dogs from Chagas disease endemic regions in Panama, Central America. Veterinary Parasitology, 178, 360-363.

Piper, P. J. (2017). The origins and arrival of the earliest domestic animals in Mainland and Island Southeast Asia: A developing story of complexity. In P. J. Piper, H. Matsumura, \& D. Bulbeck (Eds.), New perspectives in Southeast Asian and Pacific prehistory (pp. 251-274). Canberra: ANU Press.

Piperno, D. R., Ranere, A. J., Holst, I., Iriarte, J., \& Dickau, R. (2009). Starch grain and phytolith evidence for early ninth millennium BP maize from the Central Balsas River Valley, Mexico. Proceedings of the National Academy of Sciences of the United States of America, 106, 5019-5024.

Plug, I. (1989). Aspects of life in the Kruger National Park during the Early Iron Age. South African Archaeological Society Goodwin Series, 6, 62-68.

Plug, I. (1997). Early Iron Age buffalo hunters on the Kadzi River, Zimbabwe. African Archaeological Review, 14, 85-106.

Pompa y Padilla, J. A., \& Serrano Carreto, E. (2001). Los más antiguos Americanos. Arqueología Mexicana, 9, 36-41.

Prates, L. (2008). Los indígenas del Río Negro: Un enfoque arqueológico. Buenos Aires: Sociedad Argentina de Antropología.

Prates, L. (2014). Crossing the boundary between humans and animals: The extinct fox Dusicyon avus from a hunter-gatherer mortuary context in Patagonia (Argentina). Antiquity, 88, 1201-1212.

Prates, L., Berón, M., \& Prevosti, F. J. (2010a). Los perros prehispánicos del Cono Sur: Tendencias y nuevos registros. In M. Berón, L. Luna, M. Bonomo, C. Montalvo, C. Aranda, \& M. Carreza Aispitarte (Eds.), Mamül mapu: Pasado y presente desde la arqueología pampeana (pp. 215-228). Ayacucho: Editorial Libros del Espinillo.

Prates, L., Prevosti, F. J., \& Berón, M. (2010b). First records of prehispanic dogs in southern South America (Pampa-Patagonia, Argentina). Current Anthropology, 51, 273-280. 
Prevosti, F. J., Ramírez, M. A., Schiaffini, M., Martin, F., Udrizar Sauthier, D. E., Carrera, M., et al. (2015). Extinctions in near time: New radiocarbon dates point to a very recent disappearance of the South American fox Dusicyon avus (Carnivora: Canidae). Biological Journal of the Linnaean Society, 116, 704-720.

Prevosti, F. J., Zurita, A. E., \& Carlini, A. A. (2005). Biostratigraphy, systematics, and paleoecology of Protocyon Giebel, 1855 (Carnivora, Canidae) in South America. Journal of South American Earth Sciences, 20, 5-12.

Quijano-Hernández, I. A., Castro-Barcena, A., Aparicio-Burgos, E., Barbosa-Mireles, M. A., Cruz-Chan, J. V., Vásquez-Chagoyán, J. C., et al. (2012). Evaluation of clinical and immunopathological features of different infective doses of Trypanosoma cruzi in dogs during the acute phase. The Scientific World Journal, 2012, 635169.

Quijano-Hernández, I. A., Castro-Barcena, A., Vásquez-Chagoyán, J. C., Bolio-González, M. E., OrtegaLópez, J., \& Dumonteil, E. (2013). Preventive and therapeutic DNA vaccination partially protect dogs against an infectious challenge with Trypanosoma cruzi. Vaccine, 31, 2246-2252.

Raimondi, A. (1867). On the rivers San Gavan and Ayapata, in the province of Carabaya, Peru. Journal of the Royal Geographical Society, 37, 116-151.

Reimer, P. J., Bard, E., Bayliss, A., Beck, J. W., Blackwell, P. G., Bronk Ramsey, C., et al. (2013). IntCal13 and Marine13 radiocarbon age calibration curves 0-50,000 years cal BP. Radiocarbon, 55, 1869-1887.

Reinhard, K. J., \& Araújo, A. (2015). Earth oven facilities and the pathoecology of Chagas disease in the Lower Pecos canyonlands. Journal of Archaeological Science, 53, 227-234.

Richardson, D. J., Guillén, S., Beckett, R., Kyle, W., Conlogue, G., \& Harper-Beckett, K. (2012). Archaeohelminthology of the Chiribaya shepherd, Canis familiaris (700-1476 a.d.) from southern Peru. Comparative Parasitology, 79, 133-137.

Rocha, F. L., Roque, A. L. R., Arrais, R. C., Santos, J. P., dos Santos Lima, V., Xavier, S. C. C., et al. (2013a). Trypanosoma cruzi TcI and TcII transmission among wild carnivores, small mammals and dogs in a conservation unit and surrounding areas, Brazil. Parasitology, 140, 160-170.

Rocha, F. L., Roque, A. L. R., Saab de Lima, J., Cheida, C. C., Lemos, F. G., Cavalcanti de Azevedo, F., et al. (2013b). Trypanozoma cruzi infection in neotropical wild carnivores (Mammalia: Carnivora): At the top of the T. cruzi transmission chain. PLoS ONE, 8(7), e67463.

Roque, A. L. R., \& Jansen, A. M. (2014). Wild and synanthropic reservoirs of Leishmania species in the Americas. International Journal for Parasitology: Parasites and Wildlife, 3, 251-262.

Rosado, R. C. (2009). Rastreio virológico de carnívoros errantes e caracterização genética viral. Masters thesis, Universidade Técnica de Lisboa, Lisbon.

Rosenswig, R. M. (2015). A mosaic of adaptation: The archaeological record of Mesoamerica's Archaic period. Journal of Archaeological Research, 23, 115-162.

Rudolph, F. M. (2014). La gestión de los recursos animals en la prehistoria del este de Uruguay (4000 años AP-siglo XVI). PhD thesis, Universitat Autònoma de Barcelona, Barcelona.

Salomon, I. B., \& Stahl, P. W. (2008). Un enterramiento canino en Real Alto: Implicaciones para el estudio del perro prehispánico en el Nuevo Mundo. Unpublished paper presented at the III Congreso Ecuatoriano de Antropología y Arqueología.

Sandefur, E.C. (1988). Andean zooarchaeology: Animal use and the Inca conquest of the Upper Mantaro Valley. PhD thesis, University of California Los Angeles.

Savolainen, P., Zhang, Y.-P., Luo, J., Lundeberg, J., \& Leitner, T. (2002). Genetic evidence for an East Asian origin of domestic dogs. Science, 298, 1610-1613.

Schwartz, M. (1997). A history of dogs in the early Americas. New Haven: Yale University Press.

Shannon, L. M., Boyko, R. H., Castelhano, M., Corey, E., Hayward, J. J., McLean, C., et al. (2015). Genetic structure in village dogs reveals a Central Asian domestication origin. Proceedings of the National Academy of Sciences of the United States of America, 112, 13639-13644.

Shimada, M., \& Shimada, I. (1981). Explotación y manejo de los recursos naturales en Pampa Grande, sitio Moche V: Significado del análisis orgánico. Revista del Museo Nacional del Perú, 45, 19-73.

Shipman, P. (2015). The invaders: How humans and their dogs drove Neanderthals to extinction. Cambridge: Belknap Press.

Silveira, J. A. G., D’Elia, M. L., de Oliveira Avelar, I., de Almeida, L. R., dos Santos, H. A., de Magalhães Santos, D. F., et al. (2016). Rangelia vitalii in a free-ranging maned wolf (Chrysocyon brachyurus) and co-infections. International Journal for Parasitology: Parasites and Wildlife, 4, 280-285. 
Slater, G. J., Thalmann, O., Leonard, J., Schweizer, R. M., Kopefli, K.-P., Pollinger, J. P., et al. (2009). Evolutionary history of the Falklands wolf. Current Biology, 19, 937-938.

Soares, J. F., DallAgnol, B., Costa, F. B., Krawczak, F. S., Comerlato, A. T., Rossato, B. C. D., et al. (2014). Natural infection of the wild canid, Cerdocyon thous, with the piroplasmid Rangelia vitalii in Brazil. Veterinary Parasitology, 202, 156-163.

Stahl, P. W. (1984). Tropical forest cosmology: The cultural context of the Early Valdivia occupations at Loma Alta. PhD thesis, University of Illinois at Urbana-Champaign.

Stahl, P. W. (2012). Interactions between humans and endemic canids in Holocene South America. Journal of Ethnobiology, 32, 108-127.

Stahl, P. W. (2013). Early dogs and endemic South American canids of the Spanish Main. Journal of Anthropological Research, 69, 515-533.

Stahl, P. W. (2014). Perspectival ontology and animal non-domestication in the Amazon Basin. In S. Rostain (Ed.), Antes de Orellana: Actas del 3er Encuentro Internacional de Arqueología Amazónica (pp. 221-232). Lima: Instituto Francés de Estudios Andinos.

Steverding, D. (2014). The history of Chagas disease. Parasites \& Vectors, 7, 317.

Steverding, D. (2017). The history of leishmaniasis. Parasites \& Vectors, 10, 82.

Steward, J. H. (Ed.). (1948). Handbook of South American Indians, Volume 3: The tropical forest tribes. Washington: Smithsonian Institution.

Stockdale, L., \& Newton, R. (2013). A review of preventative methods against human leishmaniasis infection. PLoS Neglected Tropical Diseases, 7(6), e2278.

Stothert, K. E. (1988). La prehistoria temprana de la peninsula de Santa Elena, Ecuador: Cultura Las Vegas. Guayaquil: Museo del Banco Central del Ecuador.

Szabó, M. P. J., Mangold, A. J., João, C. F., Bechara, G. H., \& Guglielmone, A. A. (2005). Biological and DNA evidence of two dissimilar populations of the Rhipicephalus sanguineus tick group (Acari: Ixodidae) in South America. Veterinary Parasitology, 130, 131-140.

Tello, J. C., \& Xesspe, T. M. (1979). Paracas, segunda parte: Cavernas y necrópolis. Lima: Universidad Nacional Mayor de San Marcos.

Thalmann, O., Shapiro, B., Cui, P., Schuenemann, V. J., Sawyer, S. K., Greenfield, D. L., et al. (2013). Complete mitochondrial genomes of ancient canids suggest a European origin of domestic dogs. Science, 342, 871-874.

Thomas-Baker, B. (1985). Vaccination-induced distemper in maned wolves, vaccination-induced corneal opacity in a maned wolf. In Proceedings of the American Association of Zoo Veterinarians Annual Report (p. 53). Scottsdale: American Association of Zoo Veterinarians.

Tito, R. Y., Belknap, S. L., Sobolik, K. D., Ingraham, R. C., Cleeland, L. M., \& Lewis, C. M. (2011). DNA from early Holocene American dog. American Journal of Physical Anthropology, 145, 653-657.

Tolezano, J. E., Uliana, S. R. B., Taniguchi, H. H., Araújo, M. F. L., Barbosa, J. A. R., Barbosa, J. E. R., et al. (2007). The first records of Leishmania (Leishmania) amazonensis in dogs (Canis familiaris) diagnosed clinically as having canine visceral leishmaniasis from Araçatuba county, São Paulo state, Brazil. Veterinary Parasitology, 149, 280-284.

Torres, J. B. (2016). Genetic anthropology and archaeology: Interdisciplinary approaches to human history in the Caribbean. PaleoAmerica, 2, 1-5.

Troupin, C., Dacheux, L., Tanguy, M., Sabeta, C., Blanc, H., Bouchier, C., et al. (2016). Large-scale phylogenomic analysis reveals the complex evolutionary history of rabies virus in multiple carnivore hosts. PLoS Pathogens, 12(12), e1006041.

Tschopik, H. (1946). The Aymara. In J. H. Steward (Ed.), Handbook of South American Indians, Volume 2: The Andean civilizations (pp. 501-574). Washington: Smithsonian Institution.

Valadez Azúa, R. (1995). El perro mexicano. Mexico City: Instituto de Investigaciones AntropológicasUniversidad Nacional Autónoma de México.

Valadez Azúa, R., Blanco, A. P., Galicia, B. R., \& Roldán, G. P. (2013). The dog in the Mexican archaeozoological record. In C. M. Götz \& K. F. Emery (Eds.), The archaeology of Mesoamerican animals (pp. 557-582). Atlanta: Lockwood Press.

Valadez Azúa, R., Blanco, A. P., Rodríguez, B., \& Götz, C. (2009). Perros pelones del México prehispánico. Arqueobios, 3, 5-19.

van Asch, B., Zhang, A.-B., Oskarsson, M. C. R., Klütsch, C. F. C., Amorim, A., \& Savolainen, P. (2013). Pre-Columbian origins of Native American dog breeds, with only limited replacement by European dogs, confirmed by mtDNA analysis. Proceedings of the Royal Society B, 280, 20131142. 
van Heerden, J. (1979). The transmission of canine ehrlichiosis to the wild dog Lycaon pictus (Temminck, 1820) and black-backed jackal Canis mesomelas (Schreber). Journal of the South African Veterinary Medical Association, 50, 245-248.

van Heerden, J. (1980). The transmission of Babesia canis to the wild dog Lycaon pictus (Temminck) and black-backed jackal Canis mesomelas (Schreber). Journal of the South African Veterinary Association, 51, 119-120.

Vander Velden, F. F. (2008). Sobre a cães e índios. Domesticidade, classificação zoológica e relação humano-animal entre os Karitiana na Amazônia Brasileira. In IX Congreso Argentino de Antropología Social (pp. 1-20). Posadas: Facultad de Humanidades y Ciencias Sociales, Universidad Nacional de Misiones. http://www.aacademica.org/000-080/409 Site accessed 31 May 2016.

Vander Velden, F. F. (2010). Inquietas companhias: Sobre os animais de criação entre os Karitiana. PhD thesis, Universidade Estadual de Campinas.

Vilà, C., \& Leonard, J. A. (2001). Canid phylogeny and origin of the domestic dog. In E. A. Ostrander \& A. Ruvinsky (Eds.), The genetics of the dog (pp. 1-11). Wallingford: CABI.

Wei, L., Kelly, P., Ackerson, K., Zhang, J., El-Mahallawy, H. S., Kaltenboeck, B., et al. (2014). First report of Babesia gibsoni in Central America and survey for vector-borne infections in dogs from Nicaragua. Parasites \& Vectors, 7, 126.

Weyrich, L. S., Dobney, K., \& Cooper, A. (2015). Ancient DNA analysis of dental calculus. Journal of Human Evolution, 79, 119-124.

Wheeler, J., Cardoza, C. R., \& Pozzi-Escot, D. D. (1977). Estudio provisional de la fauna de las capas II y III de Telarmachay. Revista del Museo Nacional del Perú, 43, 97-109.

Wing, E. S. (1978). Use of dogs for food: An adaptation to the coastal environment. In B. L. Stark \& B. Voorhies (Eds.), Prehistoric coastal adaptations: The economy and ecology of maritime Middle America (pp. 29-42). New York: Academic Press.

Wing, E. S. (1986). Domestication of Andean mammals. In M. Vuilleumier \& M. Monasterio (Eds.), High altitude tropical biogeography (pp. 246-264). New York: Oxford University Press.

Wing, E. S. (1991). Dog remains from Sorcé site on Vieques Island. Illinois State Museum Scientific Papers, 23, 379-386.

Witt, K. E., Judd, K., Kitchen, A., Grier, C., Kohler, T. A., Ortman, S. G., et al. (2015). DNA analysis of ancient dogs of the Americas: Identifying possible founding haplotypes and reconstructing population histories. Journal of Human Evolution, 79, 105-118.

Woodroffe, R., Cleaveland, S., Courtenay, O., Laurenson, M. K., \& Artois, M. (2004). Infectious disease. In D. W. MacDonald \& C. Sillero-Zubiri (Eds.), The biology and conservation of wild canids (pp. 123-142). Oxford: Oxford University Press.

Wright, D. (2011). Frontier animal husbandry in the Northeast and East African Neolithic: A multiproxy paleoenvironmental and paleodemographic study. Journal of Anthropological Research, 67, 213-244.

Yu, P. (1997). Hungry lightning: Notes of a woman anthropologist in Venezuela. Albuquerque: University of New Mexico Press. 